NBSIR 75-920

\title{
Distribution of Water Through a Vertical Plane From Automatic Sprinkler Heads
}

Richard L. P. Custer and Klaus Wahle

Center for Fire Research

Institute for Applied Technology

National Bureau of Standards

Washington, D. C. 20234

December 1975

Interim Report

\section{Prepared for}

Division of Energy, Building Technology and Standards

Office of Policy Development and Research

Department of Housing and Urban Development

Washington, D. C. 20410 



\section{DISTRIBUTION OF WATER THROUGH A VERTICAL PLANE FROM AUTOMATIC SPRINKLER HEADS}

$\checkmark$

Richard L. P. Custer and Klaus Wahle

Center for Fire Research

Institute for Applied Technology

National Bureau of Standards

Washington, D. C. 20234

December 1975

Interim Report

Prepared for

Division of Energy, Building Technology and Standards

Office of Policy Development and Research

Department of Housing and Urban Development

Washington, D. C. 20410

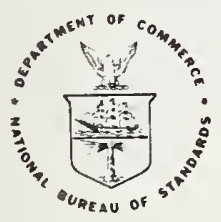

U.S. DEPARTMENT OF COMMERCE, Rogers C.B. Morton, Secretary James A. Baker, III, Under Secretary Dr. Betsy Ancker-Johnson, Assistant Secretary for Science and Technology 
Page

LIST OF FIGURES • • • • • • • • • • • • • • • • • . • . iv

LIST OF TABLES • • • • • • • • • • • • • • • • • • • •

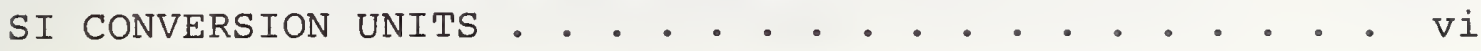

Abstract. . . . . . . . . . . . . . . . . . . . 1

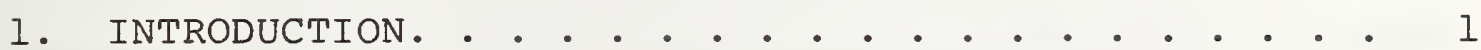

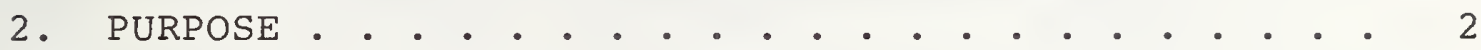

3. TEST FACILITIES AND APPARATUS . • . . • . • . . . . 3

3.1. Corridor and Doorway. . . . . . . . . . . 3

3.2. Sprinkler System and Piping . . . . . . . . 3

3.3. Sprinkler Heads . . . . . . . . . . . . 3

3.4. Instrumentation . . . . . . . . . . . . 4

4. TEST METHOD . . . . . . . . . . . . . . . . . . 4

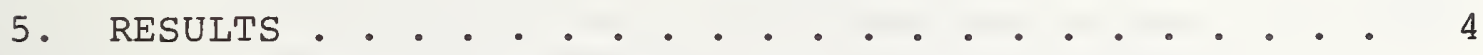

5.1. Tests for Repeatability . . . . . . . . . . 4

5.2. Average Density Through Doorway . . . . . . . 5

5.2.1. Pendent Sprinklers. . . . . . . . 5

5.2.2. Sidewall Sprinklers . . . . . . . 7

5.3. Maximum Average Density . . . . . . . . . 8

5.3.1. Pendent Sprinklers. . . . . . . . 8

5.3.2. Sidewall Sprinklers . . . . . . . . 9 9

5.4. Location of Maximum Average Density . . . . 10

5.4.1. Pendent Sprinklers. . . . . . . . 10

5.4.2. Sidewall Sprinklers . . . . . . . 11

6. CONCLUSIONS • . . . . . . . . . . . . . . . . . 11

7. ACKNOWLEDGMENTS . • . • . . . . . . . . . . . . 12

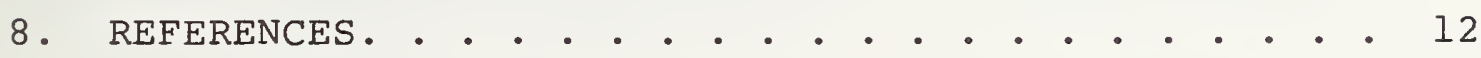


Page

Figure 1. Water Discharge Test Assembly Showing Sprinkler Locations A through F. . . .

Figure 2. Elevation of Doorway Showing water Collector and Sprinkler Locations A, B, and C. .

Figure 3. Side View of Water Collector . . . . .

Figure 4. Sectional View of Test Assembly Showing Piping Arrangement Along Centerline of Doorway . . . . . . . . . . .

Figure 5. Variations in Average Density as a Function of Manufacturer for 1/2-Inch Pendent Sprinklers in Position A . . . . . .

Figure 6. Variations in Average Density as a Function of Manufacturers for 1/2-Inch Upright Sidewalls in Position D . . . . . .

Figure 7. Row of Maximum Density as a Function of Discharge from 1/2-Inch Sprinklers in Position A . . . . . . . . . . 
Table 1. Distribution Summary - 1/2-Inch Pendent Sprinklers, Position A . . . . . . . .

Table 2. Distribution Summary - 1/2-Inch Pendent Sprinklers, Position B . . . . . . . .

Table 3. Distribution Summary - 1/2-Inch Pendent Sprinklers, Position C..... . . . .

Table 4. Distribution Summary - 1/2-Inch Sidewall Sprinklers, Position D . . . . . . .

Table 5. Distribution Summary - 1/2-Inch Sidewall Sprinklers, Position $\mathrm{E} . . . . . . .$.

Table 6. Distribution Summary - 1/2-Inch Sidewall Sprinklers, Position $\mathrm{F}$. . . . . . . .

Table 7. Distribution Summary - Small Orifice Pendent Sprinklers, Position A . . . . .

Table 8. Results of Repeatability Tests - 1/2-Inch Pendent Sprinkler at Position A Flowing 20 Gallons-per-Minute . . . . . . .

Table 9. Results of Repeatability Tests - 1/2-Inch Pendent Sprinkler at Position B, 30 Gallonsper-Minute . . . . . . . . . . . . . .

Table 10. Range of Average Density - 1/2-Inch Pendent Sprinklers . . . . . . . . . . . . .

Table 11. Range of Average Density - 3/8-Inch Pendent Sprinklers . . . . . . . . . . . .

Table 12. Range of Average Density - 1/2-Inch Upright Sidewall sprinklers

Table 13. Range of Maximum Average Density per Row of Compartments - 1/2-Inch Pendent sprinklers

Table 14. Range of Maximum Average Density per Row of Compartments - 3/8-Inch Pendent Sprinklers

Table 15. Range of Maximum Average Density per Row of Compartments - 1/2-Inch Sidewall Sprinklers 


\section{SI CONVERSION UNITS}

In view of present accepted practice in this technological area, U.S. customary units of measurement have been used throughout this report. It should be noted that the U.S. is a signatory to the General Conference on Weights and Measures which gave official status to the metric SI system of units in 1960. Readers interested in making use of the coherent system of SI units will find conversion factors in ASTM

Standard Metric Practice Guide, ASTM Designation E 380-72 (available from American Society for Testing and Materials, 1916 Race Street, Philadelphia, Pa. 19103). Conversion factors for units used in this paper are:

Length

1 in $=0.0254$ meter

$1 \mathrm{ft}=0.3048$ meter

Area

1 in $^{2}=6.4516 \times 10^{-4}$ meter $^{2}$

$1 \mathrm{ft}^{2}=9.2903 \times 10^{-2}$ meter $^{2}$

$\underline{\text { Pressure }}$

1 psi $=6895$ pascal

Volume

$1 \mathrm{gal}=3.785 \mathrm{dm}^{3}$

Density of Water Application

$1 \mathrm{gal} / \mathrm{min} / \mathrm{ft}^{2}=40.746 \mathrm{~mm} / \mathrm{min}$ 
DISTRIBUTION OF WATER THROUGH A VERTICAL

PLANE FROM AUTOMATIC SPRINKIER HEADS

Richard L. P. Custer and Klaus Wahle

Abstract

An investigation was conducted to evaluate the distribution of water through a vertical plane from automatic sprinkler heads as a function of water discharge rate and sprinkler spacing. Tests were conducted to simulate discharging an automatic sprinkler head in a corridor to determine the effectiveness of the sprinkler head in covering a doorway with water spray when positioned at various locations. Major differences in distribution characteristics between sprinkler heads produced by different manufacturers were observed. It was determined that only sprinklers installed on the centerline of the doorway and discharging water at a flow rate of 20 gallons-per-minute or more would cover the top of the doorway.

Key words: Automatic sprinklers; corridor sprinkler systems; discharge patterns; spray distribution; water distribution; water spray.

\section{INTRODUCTION}

In October 1973, the U.S. Department of Housing and Urban Development (HUD) issued changes to fire protection requirements in the Minimum Property Standards (MPS) for Multi-family [1] 1 and Care Type [2] Housing. These changes pertained to the installation of automatic sprinklers in these occupancy types. Of particular interest was the requirement for installation of automatic sprinklers in corridors, service and utility areas, and public spaces in all multi-family structures four stories or more in height and in care-type housing of fire resistive or noncombustible construction regardless of height. The only criteria presently available for design of the corridor sprinkler systems for these occupancies are found in National Fire Protection Association No. 13, Standard for Installation of Automatic Sprinklers [3]. These criteria require a minimum water application density of 0.01 gallonsper-minute-per-square-foot $\left(\mathrm{gpm} / \mathrm{ft}^{2}\right)$ on the floor and a maximum spacing of 15 feet between sprinklers.

$\bar{l}_{\text {Numbers }}$ in brackets refer to the references listed at the end of this paper. 
In March 1974, a research project, sponsored by the office of Policy Development and Research of HUD, was initiated at the National Bureau of Standards (NBS) to evaluate the current criteria and improve design in terms of spacing requirements, materials, and water discharge rates for corridor sprinkler systems as outlined in the MPS's cited above. This report contains the results of water distribution tests conducted prior to full-scale fire testing and describes the water distribution characteristics for a variety of sprinkler heads at various flow rates and spacings with respect to door opening.

\section{PURPOSE}

The ultimate design criteria suggested for corridor sprinkler protection will be based upon full-scale fire tests of sprinkler heads installed in various positions with respect to a doorway in a corridor. As a preliminary study in this program it was decided to determine the discharge characteristics (water distribution) of various types of sprinkler heads through the vertical plane of a doorway opening since this information is not available. Although nationally recognized testing laboratories, such as Underwriters' Laboratories (UL) [4] and Factory Mutual (FM) [5], conduct distribution tests on all listed and approved sprinklers, these tests are conducted to obtain discharge characteristics in the horizontal plane only. mation:

The study was designed to obtain the following infor-

1. The amount of water discharged into a doorway expressed as a percentage of total sprinkler discharge, location of maximum discharge in the door opening, total flow in gallons-per-minute (gpm), average density in gallons-per-minute-per-square-foot $\left(\mathrm{gpm} / \mathrm{ft}^{2}\right)$ over the entire opening and the maximum density $\left(\mathrm{gpm} / \mathrm{ft} \mathrm{t}^{2}\right)$ attained in any one collection area of the door.

2. The possible significant trends in discharge patterns in the plane of the doorway, such as, the concentration of water at any particular elevation in the doorway.

3. Effect of horizontal distance of the sprinkler from the door opening on the coverage of the opening by the water spray. This was studied by varying the location of the sprinkler with respect to the centerline of the doorway. 
These data were to be obtained for sprinklers of different types using various sprinkler locations and flow rates.

\section{TEST FACILITIES AND APPARATUS}

\subsection{Corridor and Doorway}

A full-scale corridor, $8 \mathrm{ft}$ wide, $12 \mathrm{ft}$ long, and $8 \mathrm{ft}$ high was constructed of exterior grade plywood, supported by a frame of nominal 2 by 4 lumber (see fig. 1). The corridor contained a doorway $3 \mathrm{ft}$ wide and $7 \mathrm{ft}-6$ in high. The doorway was partitioned into twenty-one 1-square foot slanted compartments, each provided with a drain to the rear. The water discharged into each compartment was collected in individual containers (see figs. 2 and 3 ). Water levels in the containers were converted to gallons using a calibrated dip stick.

\subsection{Sprinkler System and Piping}

A supply system of 1-inch-diameter PVC Schedule 80 pipe was installed to permit testing of pendent, vertical sidewall and horizontal sidewall sprinklers in various positions relative to the door opening (see fig. 4). A flow meter, gate valve and ball-type shut-off valve were provided to control the flow of water at the inlet of the sprinkler system (see fig. 1).

\subsection{Sprinkler Heads}

The sprinkler heads selected for testing were intended to represent a cross section of the various pendent and sidewall heads presently produced by the sprinkler industry. The pendent sprinklers included $1 / 4-, 5 / 16-, 3 / 8-, 7 / 16-$ and $1 / 2-$ inch-diameter orifice heads. The sidewall heads tested were limited to the 1/2-inch-diameter variety, since the latter represents the vast majority of sidewall heads being installed. The sidewall heads were of the vertical sidewall version (orifice discharges in the vertical plane), with the exception of one horizontal sidewall head (orifice discharges in the horizontal plane).

Automatic sprinkler heads, obtained from nine different manufacturers, were utilized in this series of tests. One "old-style" head, incorporating a characteristic deflector different from current designs, and intended for installation in either the pendent or the upright position, was included for purposes of comparison. All heads are currently listed by UL for compliance with the standard for Automatic Sprinklers for Fire Protection Service, UL 199-1969. [4] 
Flow of water through the test sprinklers was monitored using two direct-reading flow meters calibrated over the ranges of $0-15$ and 0-40 gallons-per-minute, respectively. Pressure required to obtain the desired test flow was measured using a digital display and a pressure transducer calibrated over range of 0 to 500 pounds-per-square-inch.

\section{TEST METHOD}

For each distribution test, a selected sprinkler head was successively installed in one of three locations for each type of head: positions $A, B$ and $C$ for pendent, and D, E and F for sidewall heads (see fig. l). All other sprinkler outlets were capped. A predetermined flow through the test head was established by adjusting the flow rate using a gate valve in the supply piping. When the desired flow rate was reached, the flow was terminated by closing a ball-type quick-opening valve.

Actuation of the quick-opening valve signaled the start of the test run and coincided with the start of a stop watch to record the period of water discharge. The test was terminated at the end of a 10 minute discharge, or until any one of the collection containers was filled, whichever occurred first. The amount of water collected in each container was measured, and the length of the test run was recorded. The initial test flow for each sprinkler head was set at 10 gallons-per-minute, and increased for subsequent tests by 5 gallons-per-minute until 35 gallons-per-minute was reached.

The total amount and percentage of discharge through the doorway were calculated, and the average discharge density through the doorway was determined. These data are contained in tables 1 through 7 .

It should be noted that in each test only one sprinkler head was used. It was assumed that for sprinkler heads located at positions other than on the centerline of the doorway, the cumulative effect of sprinklers installed symmetrically with respect to the door could be approximated by summing individual compartments.

\section{RESULTS}

\subsection{Tests for Repeatability}

In order to determine the reliability of the data collected using the water distribution test apparatus, a series 
of tests was conducted using the same sprinkler and flow rate for 5 repetitions in 2 different positions. The results are shown in table 8 for a pendent sprinkler flowing 20 gallonsper-minute in position $A$ and in table 9 for a pendent sprinkler flowing 30 gallons-per-minute in position $B$.

In position $A$, the standard deviation for each row expressed as the percent of the mean, ranged from 1.5 to 25.5 . The upper rows $(1-3)$ as measured from the top of the door opening, only varied to a maximum of 3.4 percent while the worst variation, 25.5 percent was found in row 7 (bottom of the door opening). Deviation in total water collected over the entire opening was 4.2 percent of the mean.

The results of the tests in position $B$ showed less variation than in position $A$. This was due at least in part to the higher flow rate which resulted in a more stable spray envelope. The lowest standard deviation was, as in the position A tests, in row 1 with a deviation of only 0.7 percent compared with 1.5 percent in position A. The highest deviation was found to be 19.1 percent in row 6 . Deviation in total water collected was only 0.9 percent of the mean.

In both test series, the deviation within row measurements was lowest in the top rows; rows 1 through 3 in position $A$ and rows 1 through 4 in position $B$. Position $C$ was not evaluated as most sprinklers tested did not reach the doorway except at flow rates of 30-35 gallons-per-minute.

\subsection{Average Density Through Doorway}

The average density through the doorway (gallons-perminute-per-square-foot) was obtained by dividing the total flow rate through the door by the total opening area of the collection compartments (see tables 1-7).

\subsubsection{Pendent Sprinklers}

In position A all 1/2-inch pendent sprinklers showed an increase in average density with increasing flow rate. The actual average density achieved for each flow rate evaluated varied considerably among sprinklers of different manufacturers (see fig. 5). The range of variation is shown in table 10 .

The range, expressed as percent difference between the highest and lowest average densities recorded,

$$
\text { (range } \left.=\frac{D_{\max }-D_{\min }}{D_{\max }} \times 100\right)
$$


varied from 78.0 percent for sprinklers A and B at 10 gallonsper-minute to 27.3 percent for sprinklers $C$ and $B$ at 30 gallons-per-minute. In this position, the percent difference decreased substantially as the flow rate increased.

In position $B$, the range of average density varied from 88.9 percent for sprinklers $D$ and $F$ at 10 gallons-per-minute to 56.1 percent for sprinklers (B) os and $B$ and $I$ at 20 gallons-per-minute. Contrary to the results obtained in position $A$, the percent difference at 35 gallons-per-minute (84.2) is nearly as high as that at 10 gallons-per-minute.

The actual values of average density in position $A$ vary from 0.022 gallons-per-minute-per-square-foot (gpm/ft ${ }^{2}$ ) for sprinkler $\mathrm{A}$ at $10 \mathrm{gpm}$ to $0.270 \mathrm{gpm} / \mathrm{ft}^{2}$ for sprinkler (B) os at $35 \mathrm{gpm}$. In position $\mathrm{B}$, the range of total density is from $0.0007 \mathrm{gpm} / \mathrm{ft}^{2}$ for sprinkler $\mathrm{D}$ at $10 \mathrm{gpm}$ to 0.114 for sprinkler A at $35 \mathrm{gpm}$. These deviations are due to changes in the shape of the spray envelope resulting from differences in deflector designs among manufacturers.

In position B, 50\% of the sprinklers tested showed an increase in average density proportional to flow rate. The remaining sprinklers showed either a temporary decrease at 20 gpm (sprinkler $F$ ) and $30 \mathrm{gpm}$ (sprinklers $B$ and $E$ ) or a continuing decrease in density at $25 \mathrm{gpm}$ and above (sprinklers $D$ and $G$ ).

Small-orifice sprinklers (1/4-inch, 5/16-inch, 3/8-inch and 7/16-inch only) were also evaluated for average density (see table 7). With the exception of sprinkler I (7/16-inch which showed a decrease at $20 \mathrm{gpm}$ and $1 / 4-$ inch showing a decrease at $15 \mathrm{gpm}$ in positions $\mathrm{A}$ and $\mathrm{B})$, all small-orifice sprinklers showed an increase in average density proportional to flow rate. Due to a lack of samples from a variety of manufacturers in the 1/4-,5/16- and 7/16-inch sizes a comparison of the range of average densities could not be made. A comparison of data from two manufacturers of $3 / 8$-inch sprinklers, however, is shown in table ll. In both positions $A$ and $B$, the percent difference between the two samples is greater at the higher flow rates than at low flow rates. This is again due to variations in deflector designs. At the high pressures necessary for development of 20 gpm flow rates many more small droplets are generated. The small droplets have a higher drag coefficient and thus, reach terminal velocity sooner. This is shown by the decrease in average density from $0.018 \mathrm{gpm} / \mathrm{ft}^{2}$ at $10 \mathrm{gpm}$ to $0.017 \mathrm{gpm} / \mathrm{ft}^{2}$ at 15 gpm for sprinkler I in position B. The increase to an average density of $0.023 \mathrm{gpm} / \mathrm{ft}^{2}$ at $20 \mathrm{gpm}$ is most likely due to increased flow rate. The end result is a decrease in the volume of the spray envelope. This effect can also be noted in the data for the 1/4- and 7/16-inch orifice sprinklers (see table 7). 
The range in average density for the 3/8-inch sprinkler in position $\mathrm{A}$ is from $0.043 \mathrm{gpm} / \mathrm{ft}^{2}$ at $15 \mathrm{gpm}$ to $0.105 \mathrm{gpm} /$ $\mathrm{ft}^{2}$ at $20 \mathrm{gpm}$. The range of average density in position $B$ varies from 0.017 to $0.069 \mathrm{gpm} / \mathrm{ft}^{2}$.

\subsubsection{Sidewall Sprinklers}

Seven sidewall sprinklers were tested in positions D, E and F. Six were upright and one was of the recently developed horizontal type. The results of these tests are shown in tables 4 through 6 .

Three of the upright sidewalls tested in position $\mathrm{D}$ had increasing average density proportional to flow (B, D and G) while the other three showed fluctuations in average density as flow increased. Sprinkler A decreased from 0.313 to 0.169 $0.169 \mathrm{gpm} / \mathrm{ft}^{2}$ from 10 to $15 \mathrm{gpm}$ then increased to a maximum of $0.317 \mathrm{gpm} / \mathrm{ft}^{2}$ at $35 \mathrm{gpm}$. A similar pattern was evidenced with sprinkler B while sprinkler E dropped at $20 \mathrm{gpm}$, increased at 25, dropped at 30 and increased again at $35 \mathrm{gpm}$.

In position $E$, only 2 of the upright sidewalls exhibited downward variations in average density. Sprinkler A decreased from 0.139 to $0.056 \mathrm{gpm} / \mathrm{ft}^{2}$ between 30 and $35 \mathrm{gpm}$. This was due to a collapse of the spray envelope as discussed above. Although this collapse is evident visually in position $D$, it is not indicated in the data until the sprinkler is off-set from the centerline of the door (position $\mathrm{E}$ ).

The distribution performance for the upright sidewalls was generally poor in position F. Sprinkler C did not discharge any measurable water through the door until a flow of $30 \mathrm{gpm}$ was reached. At this point, the average density was only $0.012 \mathrm{gpm} / \mathrm{ft}^{2}$ as compared to 0.044 at position $\mathrm{E}$ and 0.079 at position D. Sprinkler A showed the same envelope collapse at $35 \mathrm{gpm}$ as evidenced in position $\mathrm{E}$.

The range of average density variation between manufacturers for upright sidewalls is very great (see fig. 6). The range of variation is shown in table 12 . In position $D$ the range varies from 87.6 percent at $15 \mathrm{gpm}$ to 77.8 percent at $25 \mathrm{gpm}$. With the exception of $25 \mathrm{gpm}$, all flows yield differences greater than 80 percent. In position $E$, the range is very similar with the notable exception that the smallest percent difference occurs at $35 \mathrm{gpm}$. The total range of average densities recorded varies from $0.021 \mathrm{gpm} / \mathrm{ft}^{2}$ for sprinkler $B$ at $15 \mathrm{gpm}$ to $0.317 \mathrm{gpm} / \mathrm{ft}^{2}$ for sprinkler A at $35 \mathrm{gpm}$ in position $\mathrm{D}$. The range for position $\mathrm{E}$ varies from $0.004 \mathrm{gpm} / \mathrm{ft}^{2}$ for sprinkler $\mathrm{E}$ at $10 \mathrm{gpm}$ to $0.139 \mathrm{gpm} / \mathrm{ft}^{2}$ for sprinkler $A$ at $30 \mathrm{gpm}$. 
only one sample of a horizontal sidewall sprinkler was available. The data for this sample are shown in tables 4 through 6. In position D, the average density increases by a factor of 3.6 from 10 to $15 \mathrm{gpm}$ and by a factor of 2.3 from 15 to $35 \mathrm{gpm}$. This represents the greatest rate of change of all the sidewalls tested. This results from the fact that the water strikes the deflector in the same plane as the resultant spray. This eliminates the 90 degree change in direction associated with upright sidewalls and imparts greater momentum to the droplets developed.

\subsection{Maximum Average Density}

The maximum average density was obtained by averaging the water collected in all 3 bins for each row and choosing the value for the row with the maximum average density. This number represents the greatest density which can be obtained for a given flow rate across a l-foot high, 3-foot wide segment of the door opening.

\subsubsection{Pendent Sprinklers}

As was the case with average density, the maximum average density varies greatly with both the manufacturer, the position of the sprinkler with respect to the door opening, and the operating flow rate. The data for positions A, B and C are contained in tables 1 through 3 .

In position $\mathrm{A}$, the maximum average density increased proportionally with flow rate with a few exceptions. Sprinkler C, for example, had a decrease from 0.310 to $0.252 \mathrm{gpm} /$ $\mathrm{ft}^{2}$ between 25 and $30 \mathrm{gpm}$. The same phenomenon was observed for sprinkler $F$ which dropped from 0.703 to $0.642 \mathrm{gpm} / \mathrm{ft}^{2}$ over the same flow rates.

In position B, all sprinklers except one showed substantial increases in maximum average density with flow rate. Sprinkler $A$ and $D$ showed a continuous increase within experimental error with flow rate. Sprinklers B(os) and G showed decreases between 30 and $35 \mathrm{gpm}$ of 56.9 and 79.9 percent, respectively. The remaining 6 sprinklers showed a decrease when the flow changed from 25 to $30 \mathrm{gpm}$. The percent decrease ranged from 11.7 for sprinkler B to 47.1 for sprinkler $F$. This indicates that there exists, for each sprinkler, a flow rate at which a significant decrease in the density of application occurs. This flow rate is most easily determined by evaluating the maximum average density in a position other than on the centerline of the door opening. 
The range of maximum average density as a function of manufacturer for 1/2-inch pendent sprinklers in positions $A$ and $B$ is shown in table 13. In position $A$ the range is from 61.7 percent at $30 \mathrm{gpm}$ to 84.8 percent at $10 \mathrm{gpm}$. The range in position B varied from 94.9 percent at $35 \mathrm{gpm}$ to 78.6 percent at $20 \mathrm{gpm}$. The same phenomenon of a large percent difference at $35 \mathrm{gpm}$ versus that at $20 \mathrm{gpm}$ was noted in position $B$ as occurred with the total density (see table 10). This is due to collapse of the spray envelope as discussed in 5.2.1. above.

The maximum average density data for small-orifice sprinklers are shown in table 7. In position A, the 1/4-inch sprinkler tested showed a 77.8 percent drop from 10 to $15 \mathrm{gpm}$ due to the generation of a very fine spray and envelope collapse at the pressures required to attain the higher discharge rate. The 5/16- and 3/8-inch orifice sprinklers showed an increase in maximum average density with flow rate while the 7/16-inch sprinkler showed a 27.8 percent drop between 25 and $28 \mathrm{gpm}$ (the highest flow rate obtainable at the pressures used). In position $B$, the 3/8-inch sprinkler (A) showed a 71.6 percent decrease between 20 and $24 \mathrm{gpm}$, and the 7/16-inch sprinkler (I) a 38.1 percent decrease between 29 and $35 \mathrm{gpm}$.

The range of maximum average density for 3/8-inch pendent sprinklers is shown in table 14. In position $A$ the smallest difference was 49.7 percent at $15 \mathrm{gpm}$ and the largest difference, 66.4 percent was found at $20 \mathrm{gpm}$. In position $\mathrm{B}$, the range was 30.2 percent at $10 \mathrm{gpm}$ to 86.6 percent at $20 \mathrm{gpm}$.

\subsubsection{Sidewall Sprinklers}

The maximum average density data for the sidewall sprinklers tested are contained in tables 4 through 6 . In position $A$, three sprinklers (C, D and G) showed continuous increase in maximum average density with flow rate. Sprinklers $B$ and $E$ showed a decrease between 10 and $15 \mathrm{gpm}$, and $\mathrm{A}$ showed a decrease between 20 and $25 \mathrm{gpm}$ followed by an increase up to $35 \mathrm{gpm}$. In position B, only sprinkler D had a continuous increase in maximum average density. Sprinkler A showed a 50 percent drop between 30 and $35 \mathrm{gpm}$, while $\mathrm{C}$ showed a 10 percent decrease between 25 and $30 \mathrm{gpm}$ and $\mathrm{G}$ dropped 40 percent between 15 and $20 \mathrm{gpm}$. Although maximum average densities obtained in position $B$ were less than those in position A the other sidewall sprinklers showed the same shift patterns as in position $\mathrm{A}$.

The horizontal sidewall tested showed changes in maximum average density with flow rate which reflected the changes in total density discussed in 5.2.2. above with the exception that a decrease in maximum average density occurred between 20 
and $25 \mathrm{gpm}$ while no decrease was noted in total density at these flow rates. This is due to a shift in the distribution of water within the spray envelope as indicated by the fact that the row of maximum density shifted from row 2 to row 1 as the flow rate increased.

The range of maximum average densities recorded for the sidewall sprinklers tested is shown in table 15. In position $A$, the percent difference in all cases was greater than 90.2 percent. In position $B$, the results were not much better. The range varied from 73.9 to 85.5 percent.

\subsection{Location of Maximum Average Density}

To use automatic sprinklers as a barrier to heat flow through a door opening, the distribution characteristic of primary importance is the degree of coverage obtained in the upper portion of the doorway opening. It is in this area that the temperatures and mass flow rates of the hot gases will be greatest. In order to study this characteristic, data regarding the vertical position of the maximum average density was collected for each sprinkler and flow rate tested. The results are shown in tables 1 through 7 with specific comments regarding dry or only slightly wetted areas included. The location of maximum density is described in terms of feet below the bottom of the lintel of the doorway or row number in which the maximum average density was achieved. This location depends primarily on flow rate for any given position of the sprinkler with respect to the doorway opening.

\subsubsection{Pendent Sprinklers}

The location of maximum density in position A for 1/2inch pendent sprinklers is related to the discharge rate and varies with the manufacturer's design (see fig. 7). Sprinkler A, for example, shows no water on the top 2 rows at $10 \mathrm{gpm}$ with row 7 as the location of maximum density. At $20 \mathrm{gpm}$, row 1 gets 50 percent of the total flow through the door. Sprinkler D, by contrast, has its maximum density in row 4 up to $20 \mathrm{gpm}$. Between 20 and $30 \mathrm{gpm}$ row 3 has the highest density and at $30 \mathrm{gpm}$ the maximum density drops to row 4 again as the spray envelope collapses. With the exception of sprinkler D, all 1/2-inch pendent sprinklers tested completely covered the upper portions of the door opening. The variation in density among sprinklers of different manufacturer's design, however, was considerable (see table 13). This statement also applies to position B. It should be noted, however, that the densities achieved in position $B$ are often much lower than in position A. An example of this is sprinkler $\mathrm{F}$ (see table 13). 
The percent reduction between the two positions varies from 50 percent at $10 \mathrm{gpm}$ to 9 percent at $15 \mathrm{gpm}$ and 60 percent at 25 $\mathrm{gpm}$. This is true, in general, for small-orifice sprinklers as well (see table 7). With the exception of sprinkler A at $15 \mathrm{gpm}$, no water reaches the top row in position $\mathrm{C}$.

\subsubsection{Sidewall Sprinklers}

For the sidewall sprinklers tested in position D, only 1 (sprinkler A) continuously discharges through row 1 at all flow rates. Sprinkler $C$, by contrast, only discharges a trace of water to the top row. With the exception of sprinkler $C$, all sidewall sprinklers wet the top row at $25 \mathrm{gpm}$ and above. In position $E$, the same situation is true with the exception that the densities decrease up to 74 percent between position $D$ and $E$ (see table 15). Without exception, no water reaches row 1 in position $F$ at the highest flow rate tested.

\section{CONCLUSIONS}

Based on the results of the water distribution study the following conclusions have been reached:

1. The test apparatus used to study the distribution of water from automatic sprinklers through a vertical opening produces repeatable data and has potential for becoming a future test method.

2. Sprinklers located in positions other than $A$ and $D$ will leave portions of the upper part of the door opening without water coverage even when two sprinklers are located symmetrically about the centerline of the door. In positions $C$ and $F$ ( 7.5 feet from the centerline of the door) none of the sprinklers tested discharged significant water through the doorway opening. Obviously, for all sprinklers studied, position $A$ and $D$ (on the centerline of the door opening) provide the highest total coverage of the opening. This is important if the sprinklers are to provide protection from hot gases issuing from a doorway.

3. A flow rate of $20 \mathrm{gpm}$ or higher in positions $A$ and $D$ is necessary if the top of the door opening is to be covered. The flow rate for the final design criteria will require fire testing with the spray exposed to an actual thermal load. 
4. Although average density and maximum average density generally increase with increasing flow rate, some sprinklers tested showed decreases in these parameters at high flow rates. Most of the variations were found above $25 \mathrm{gpm}$. This is most likely due to momentum and drag effects resulting from variations in drop size due to deflector design. More detailed study of this phenomenon could lead to a method for prediction of these variations.

5. Major differences exist among various sprinkler manufacturers with regard to all the distribution parameters studied. For this reason, interim design criteria for corridor sprinkler protection, as defined in the MPS', will have to be based on the position and flow rate, as determined in fire tests, which will provide adequate protection with all available sprinklers pending the development and acceptance of an appropriate performance-based test procedure.

\section{ACKNOWLEDGMENTS}

The authors wish to express particular thanks to Messrs. Henry Wheelock and Richard Zile of the Program for Fire Detection and Control systems for their assistance in the construction of the test apparatus and collection of the discharge data.

\section{REFERENCE}

[1] Minimum Property Standards for Multi-family Housing, HUD 4910.1, Department of Housing and Urban Development, Washington, D.C., 1973 Edition.

[2] Minimum Property Standards for Care-Type Housing, HUD 4920.1, Department of Housing and Urban Development, Washington, D.C., 1973 Edition.

[3] Installation of Automatic Sprinkler Systems, NFPA No. 13, National Fire Protection Association, Boston, Mass., 1975 Revision.

[4] Standard for Automatic Sprinklers for Fire Protection Service, Underwriters' Laboratories 199, Underwriters' Laboratories, Inc., Northbrook, Il.

[5] Distribution and Fire Test Performance of Standard Sprinklers, Factory Mutual Approval Standard, Class No. 5-2001, 2002, 2013, 2015, 2016 and 2017, Factory Mutual Research Corporation, Norwood, Mass. 


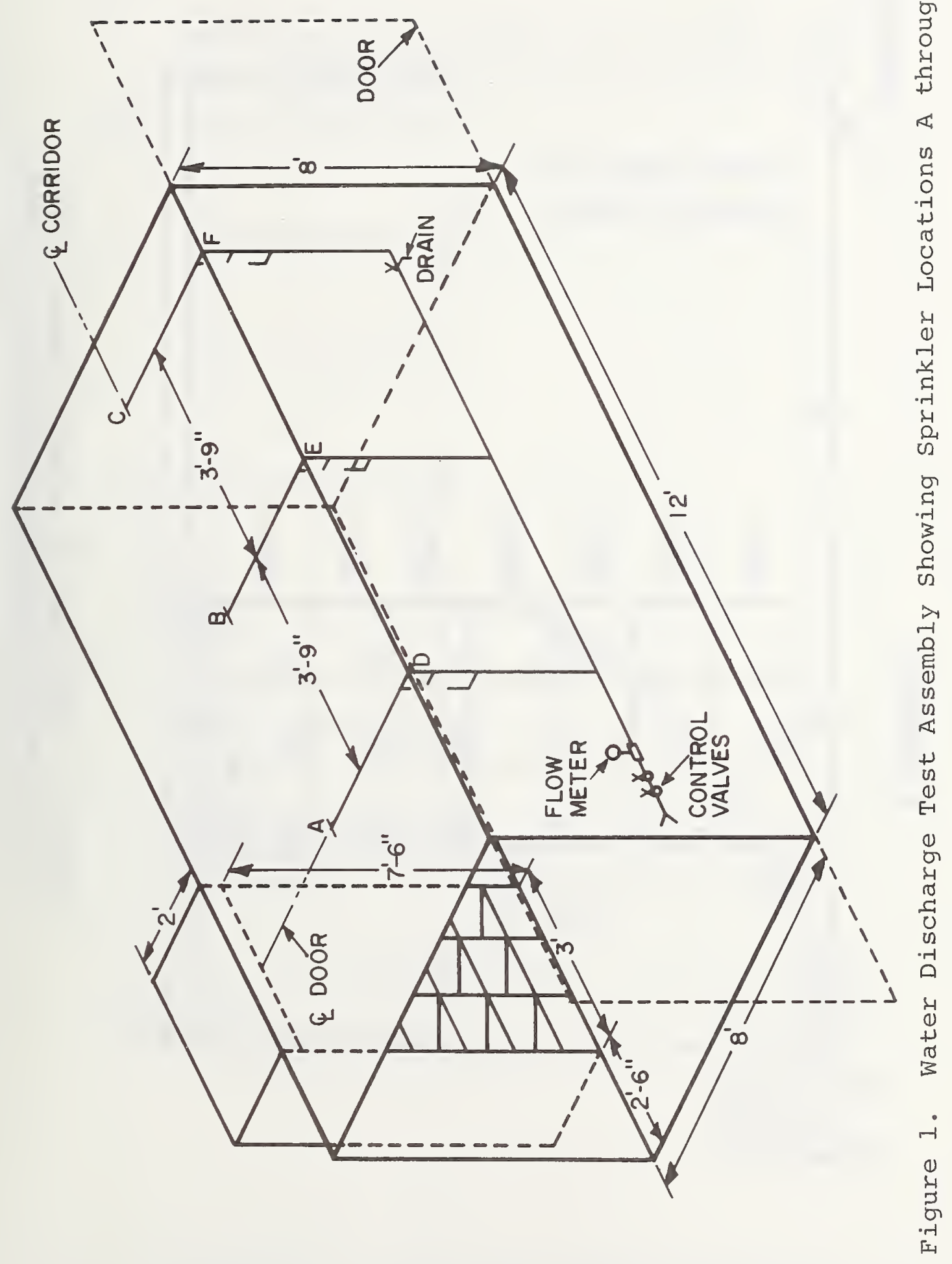











Typical Water Collecting Arrangement

Figure 3. Side View of Water Collector 


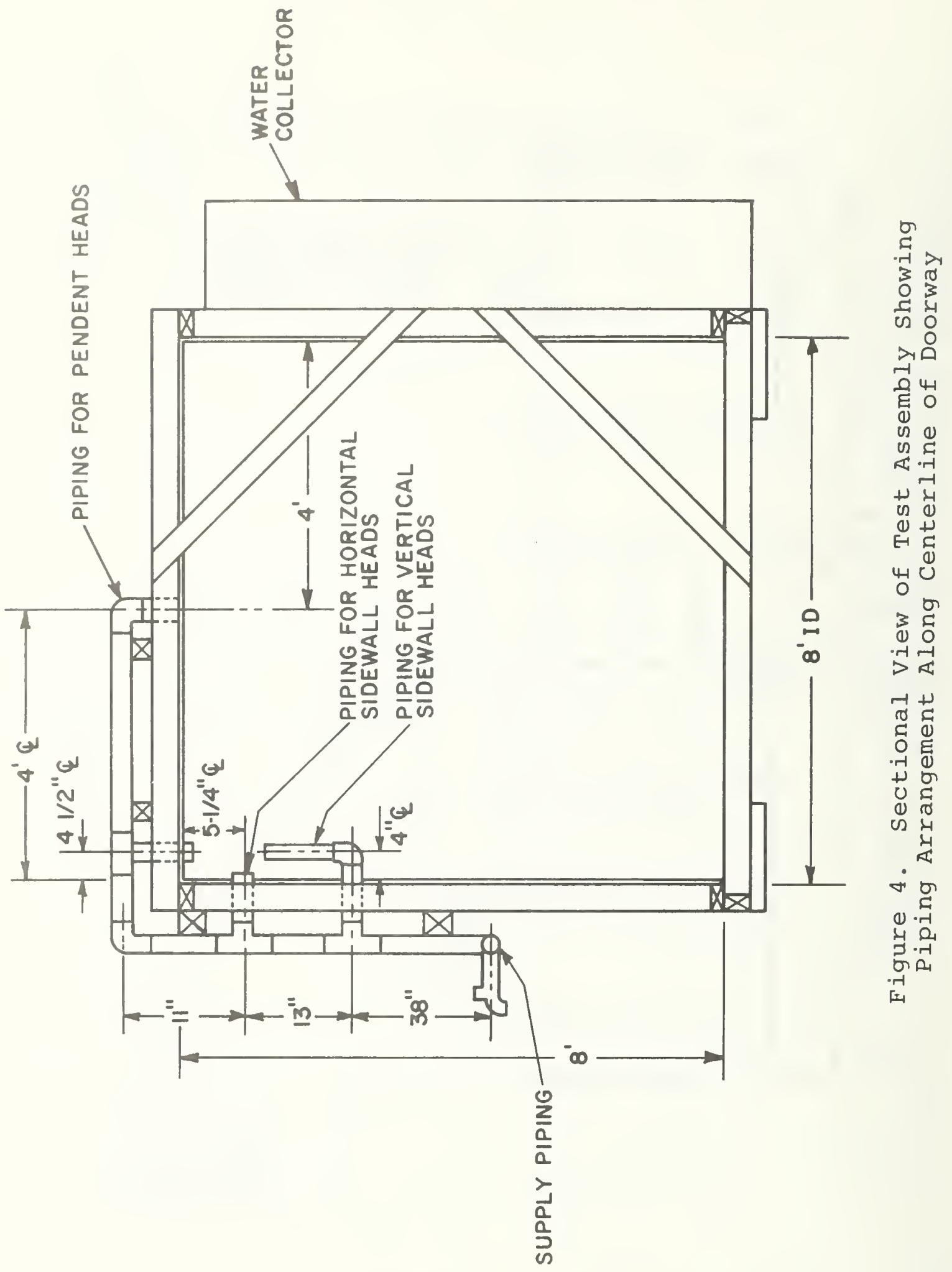






Figure 5. Variations in Average Density as a Function of Manufacturer for 1/2-Inch Pendent sprinklers in Position A. 




Figure 6. Variations in Average Density as a Function of Manufacturer for 1/2-Inch Upright Sidewalls in Position D. 


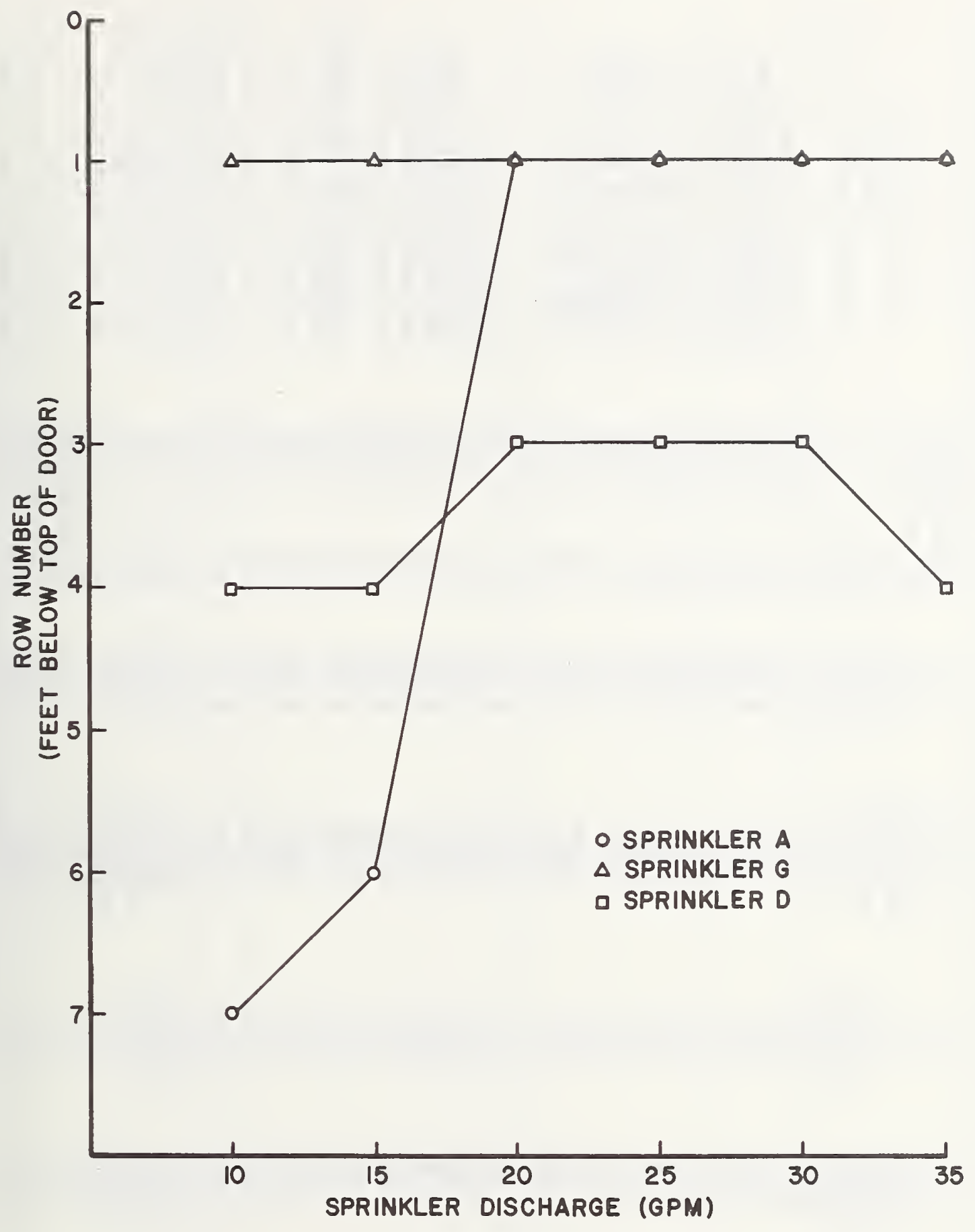

Figure 7. Row of Maximum Density as a Function of Discharge from 1/2-Inch Sprinklers in Position A 


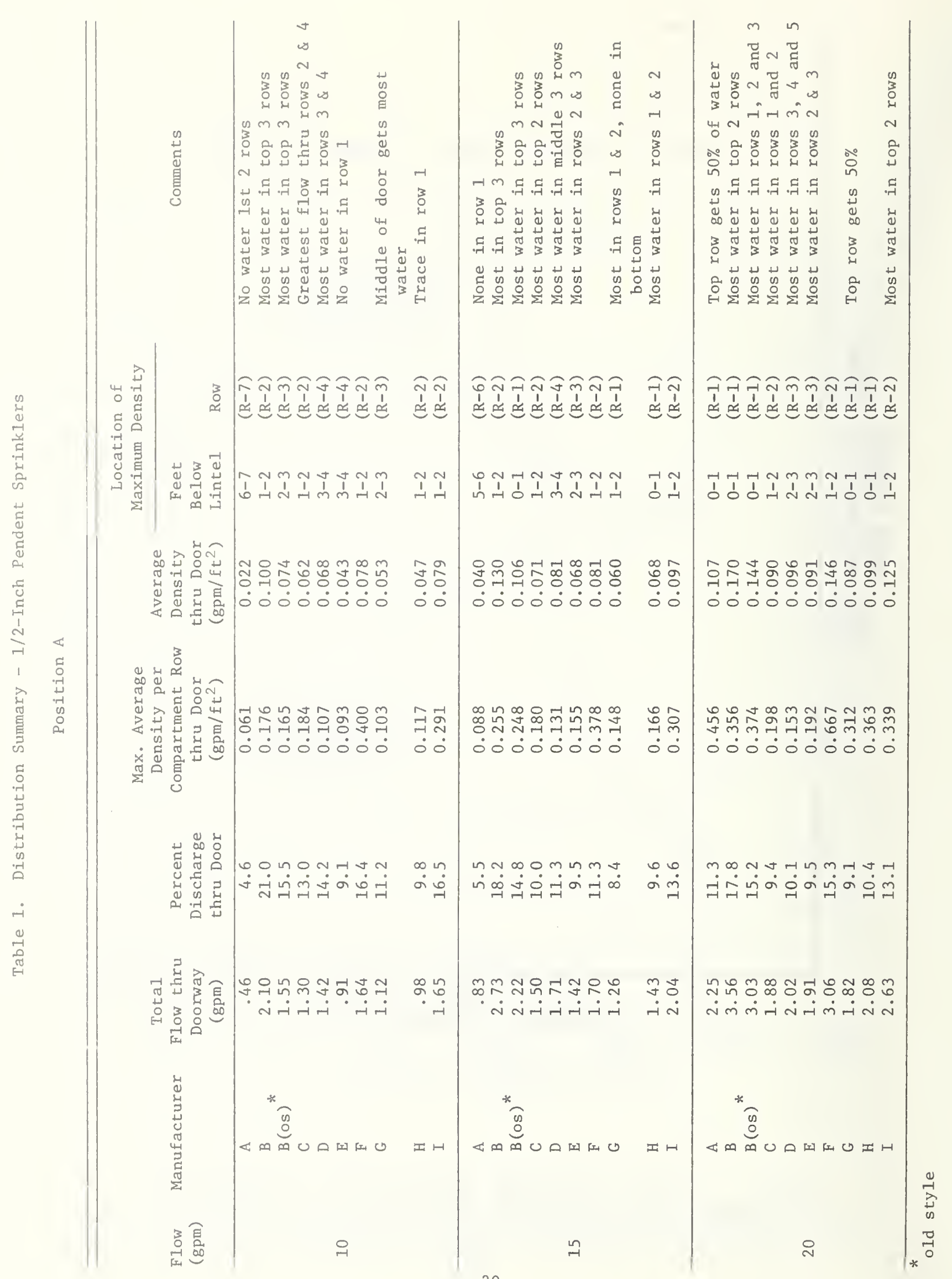




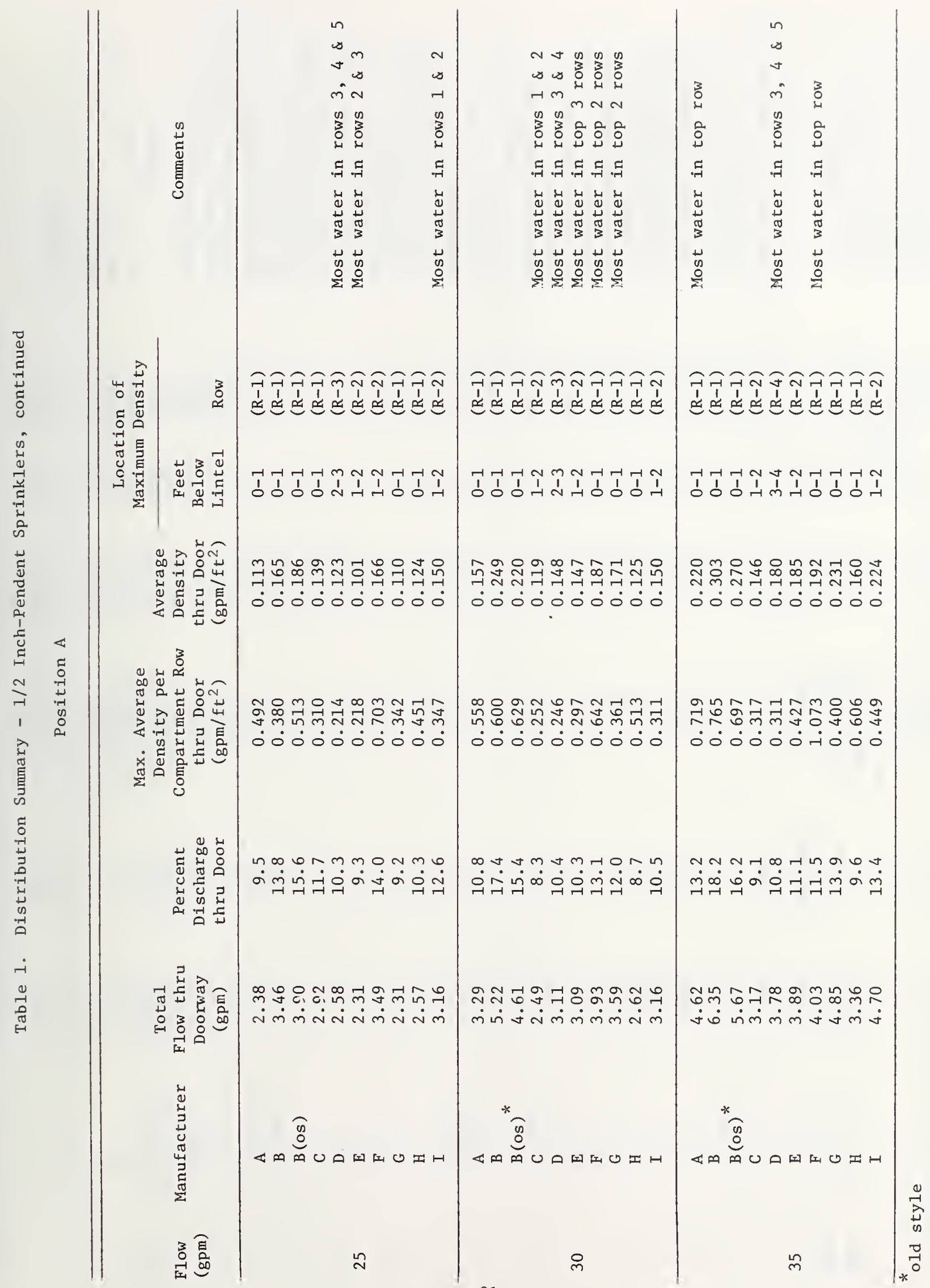




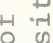

동 巳ั

더 $\mathrm{E}$

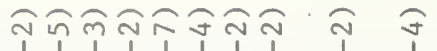

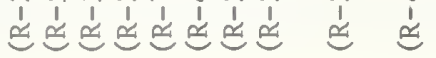

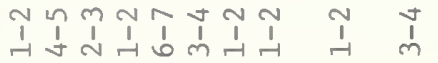
ํㅡㅇㅡำ $\infty_{0.1}^{\infty}$ क्र 02 $\gtrless \stackrel{0}{\circ}$

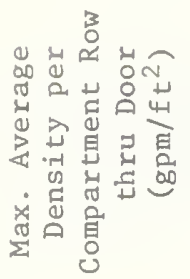
落 范 : 象

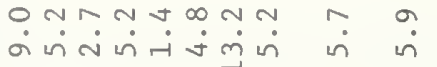
m๊ิ ல் $\dot{0} \dot{0} \dot{0} \dot{0} \dot{0}$

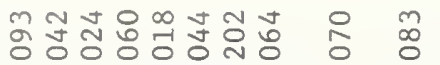
லं்ட்0் $\dot{0} \dot{0}$

귕ํํㅇㅇㅇㅇ Ð $\dot{0} \dot{0} \dot{0} \dot{0} \dot{0} \dot{0} \dot{0}$

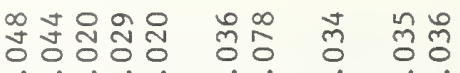
$\dot{0} \dot{0} \dot{0} \dot{0} \dot{0} \dot{0} \dot{0} \dot{0}$

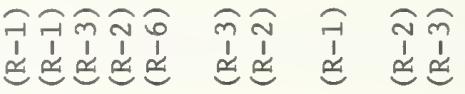

İ)

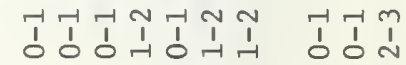


$0 \cdot 000.0$



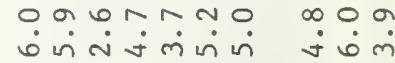

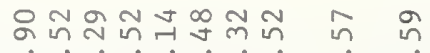


ல0ல00்-10 $\dot{0}$

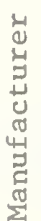
会

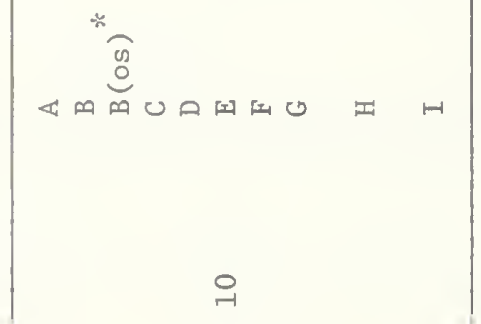

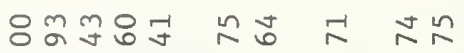
-i்0் $\dot{0} \dot{0} \dot{0} \dot{0}$<smiles>[C+]1C=C[CH-]1</smiles>
$4 \infty$


ல் $\dot{0} \dot{0} \dot{0} \dot{0} \dot{0} \dot{0}$

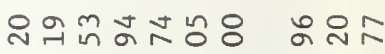

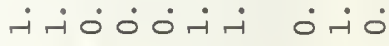<smiles>[C+]1CCCCC1</smiles>
क \& 


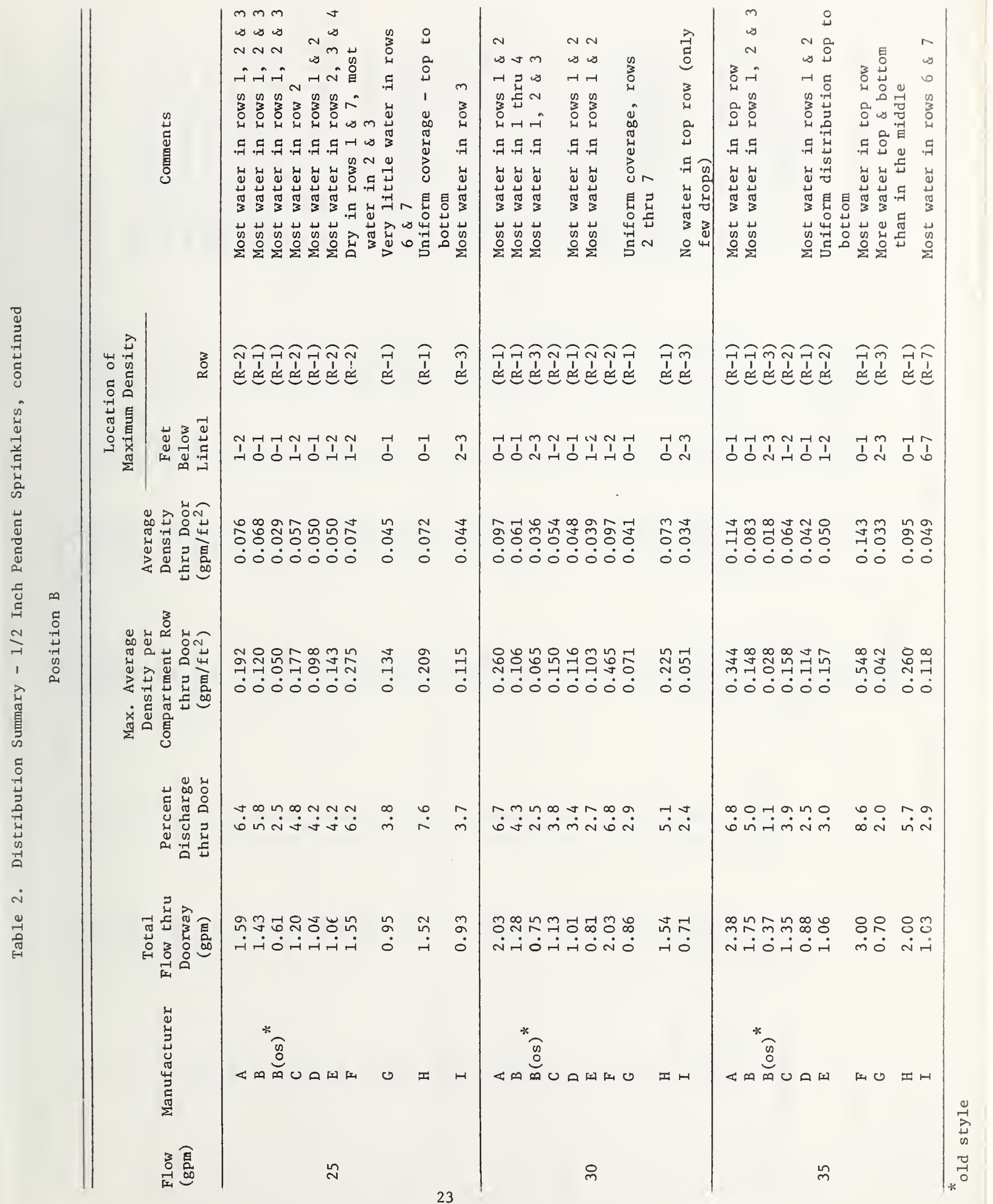









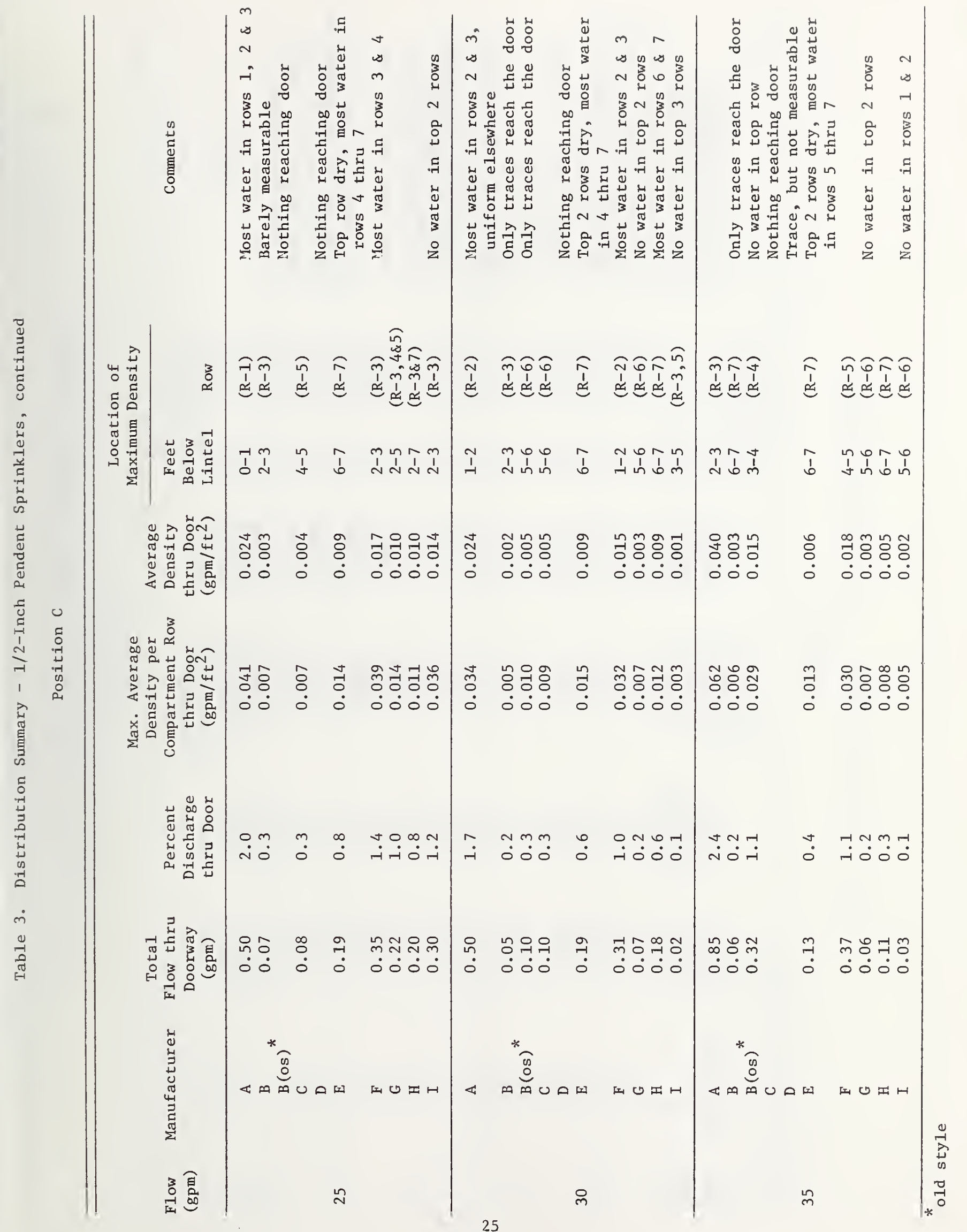




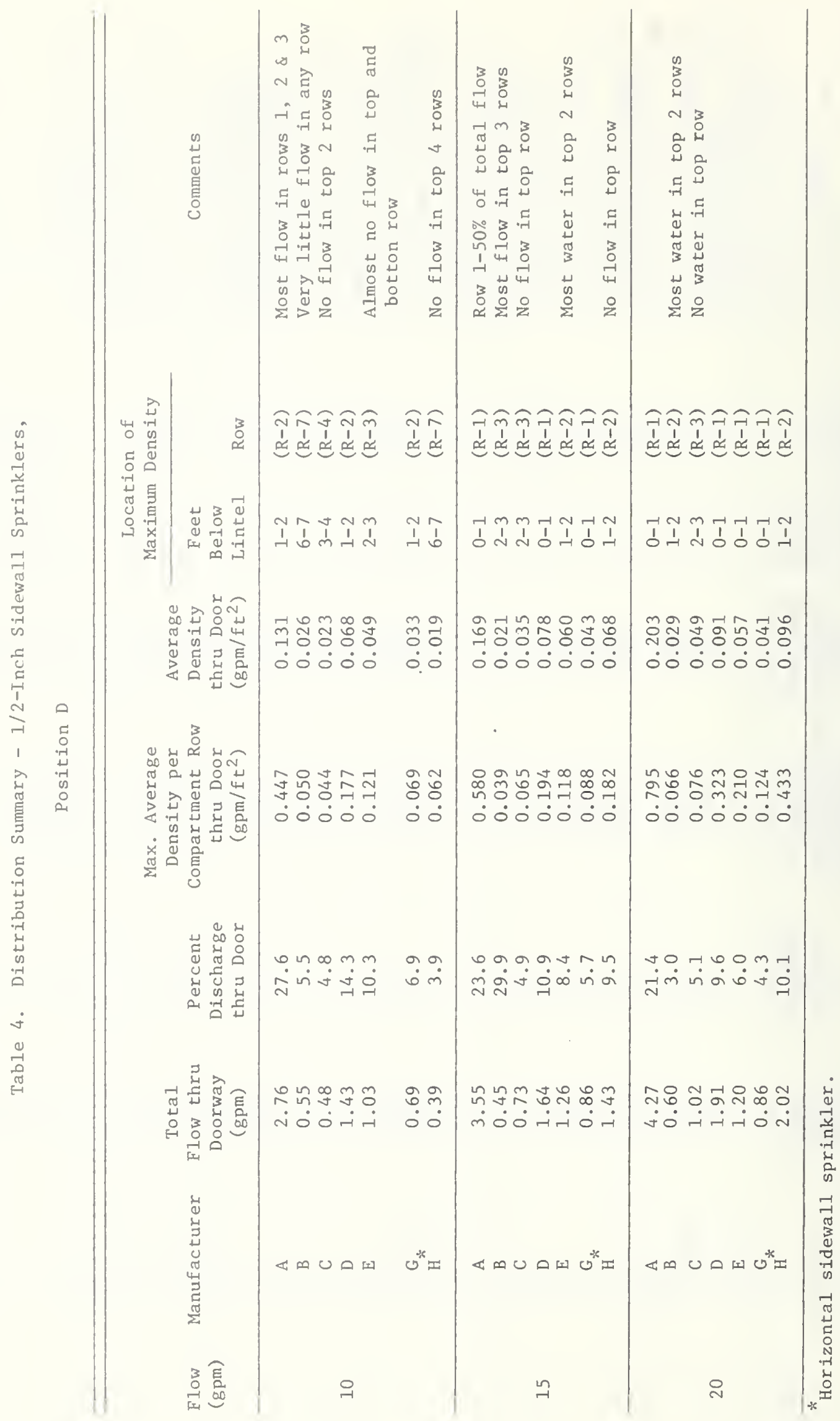




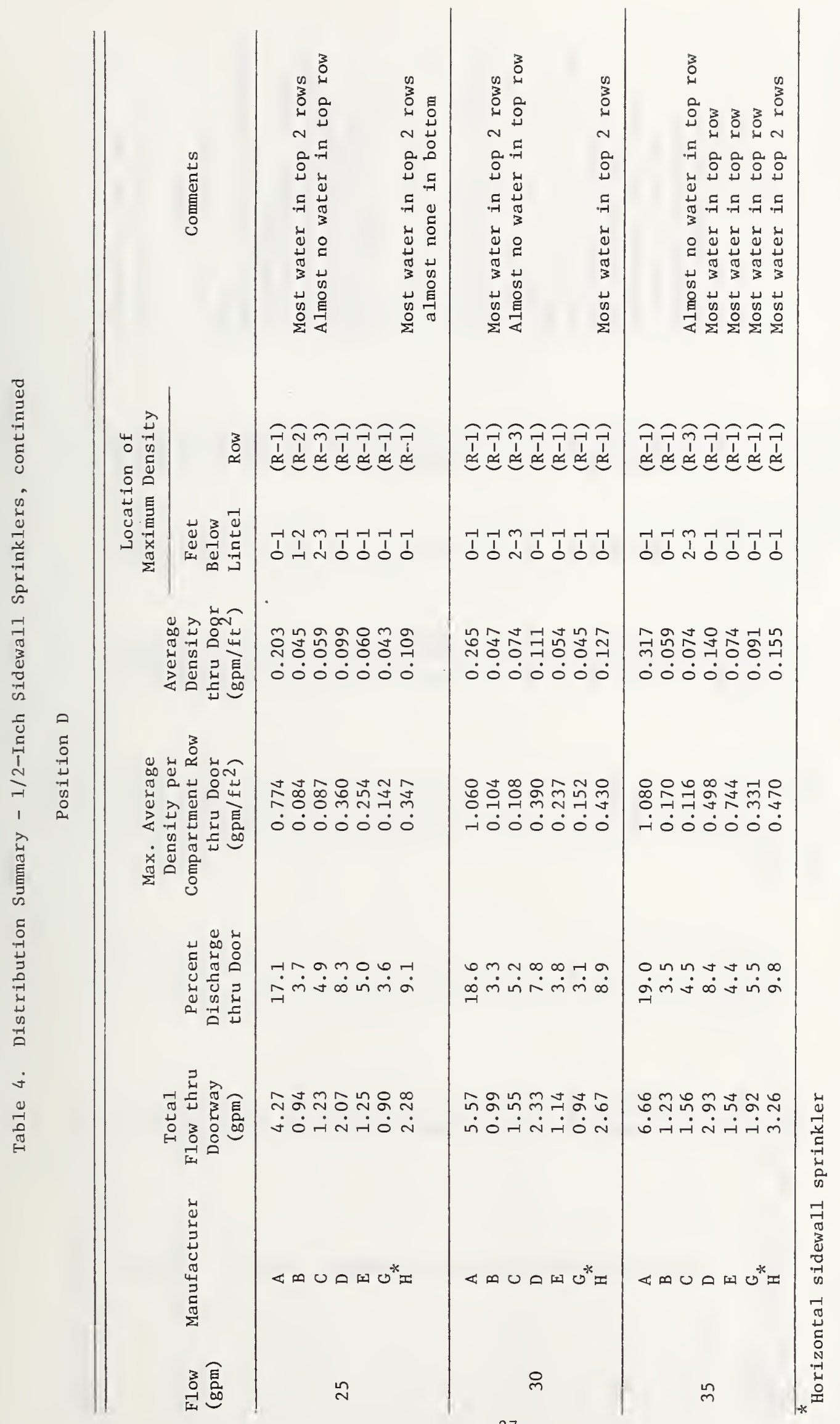




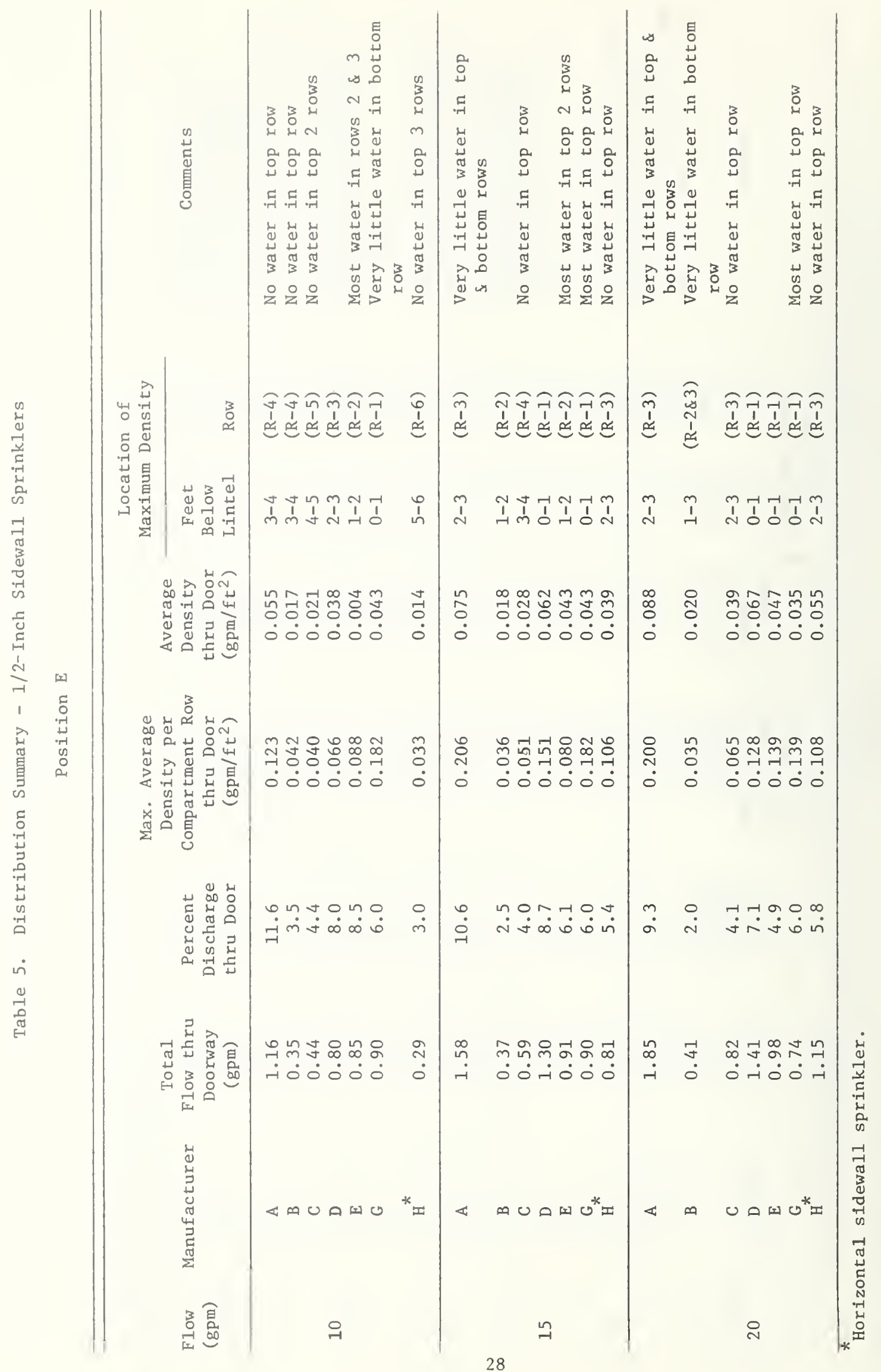




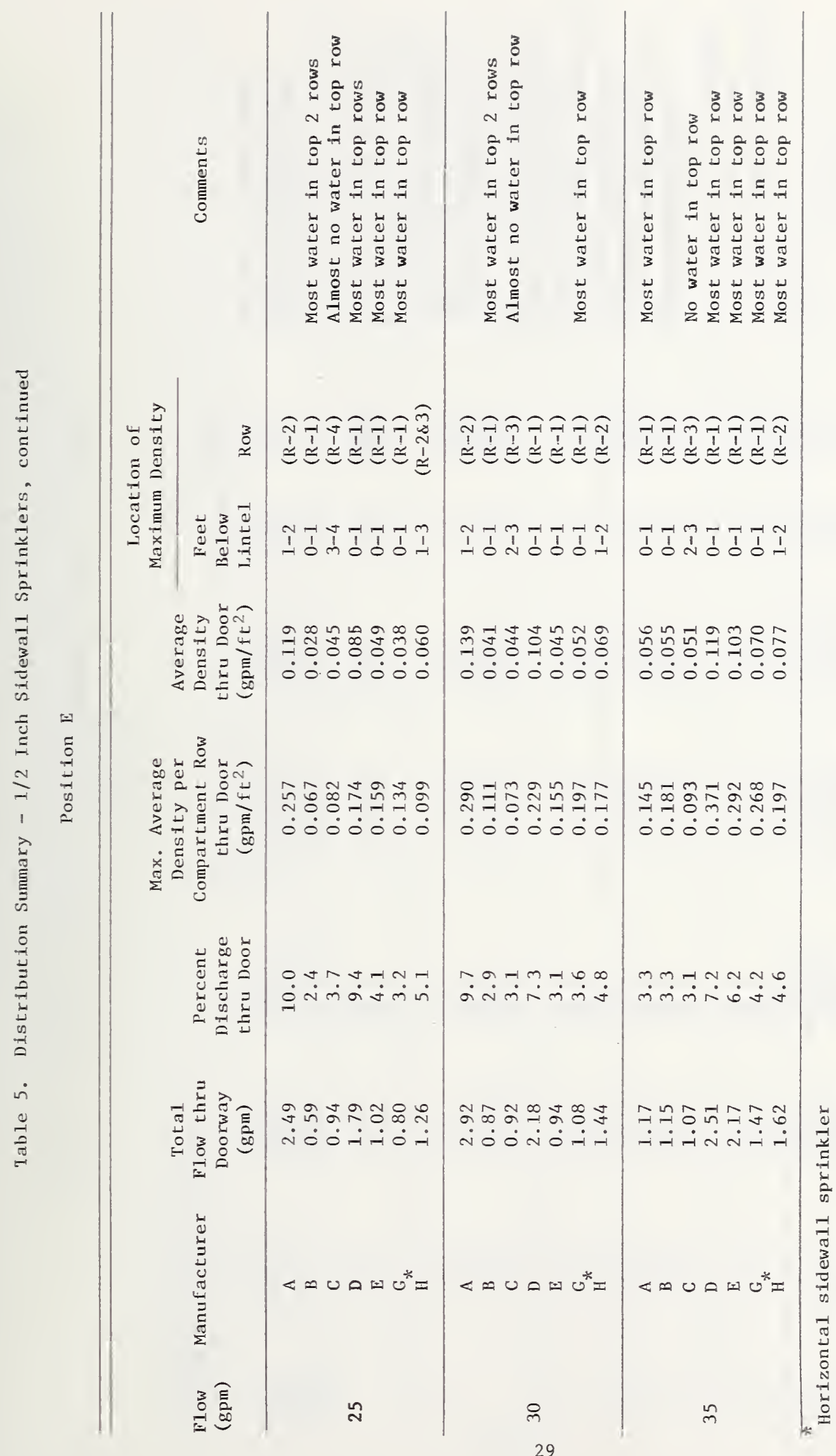




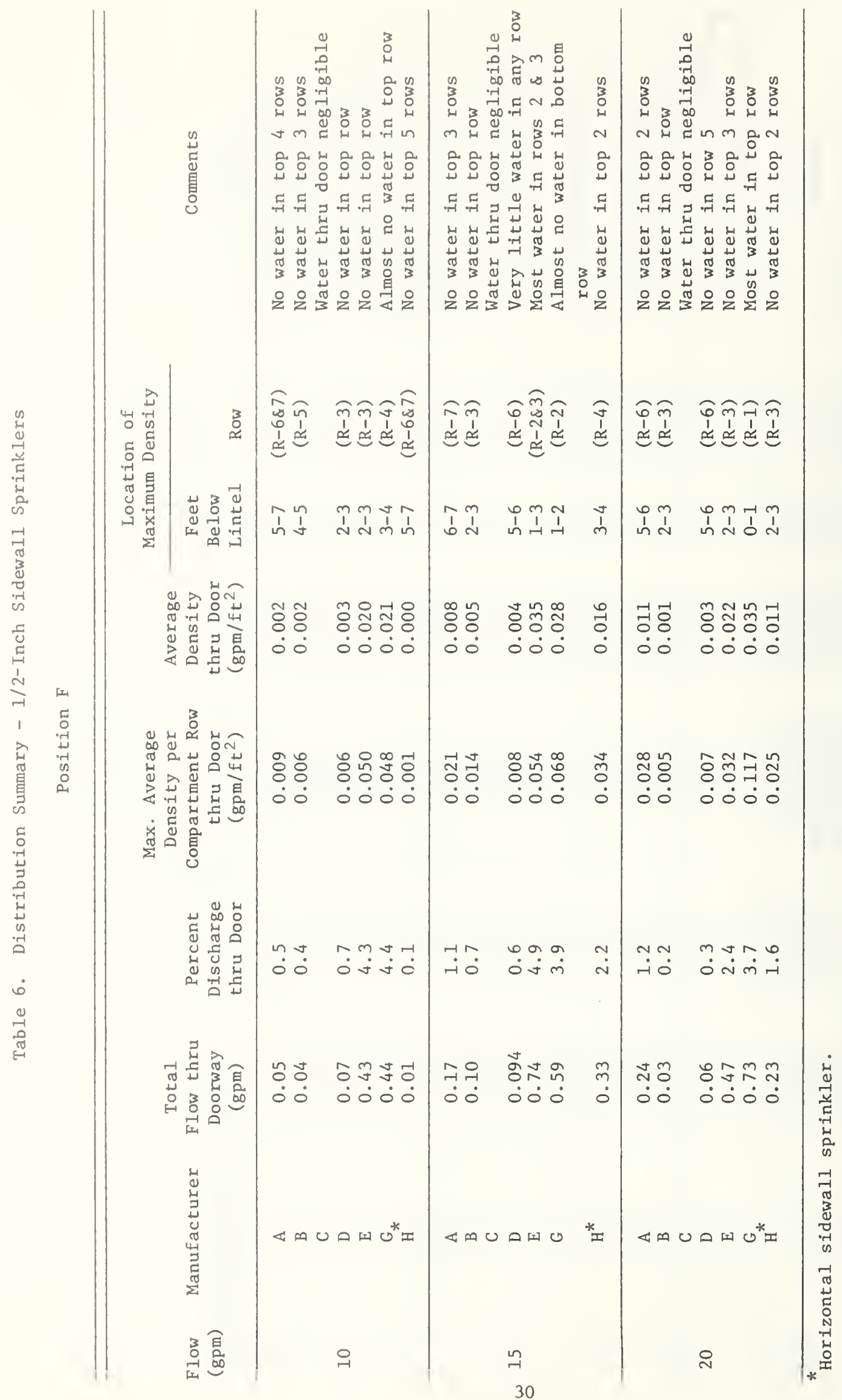




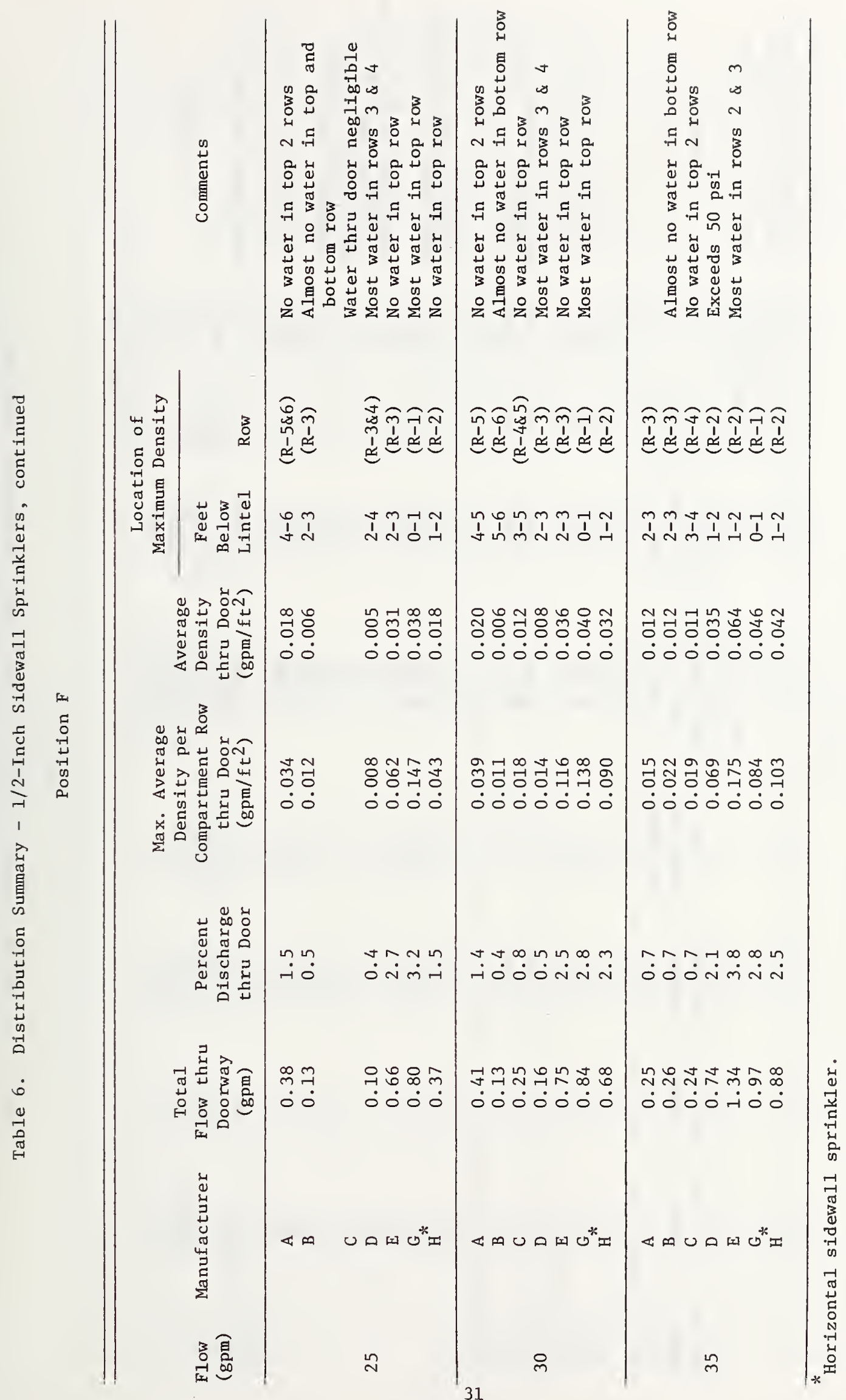




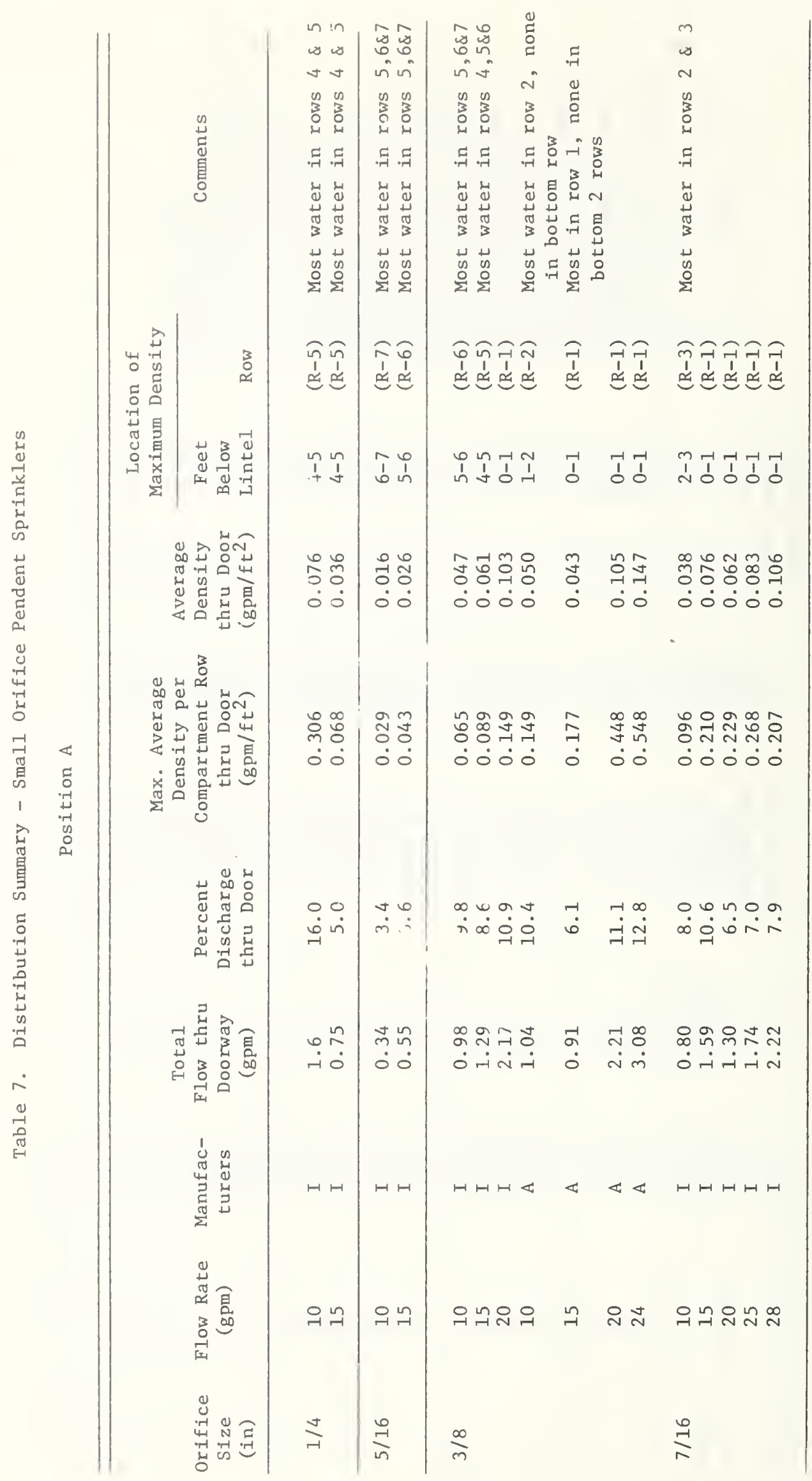




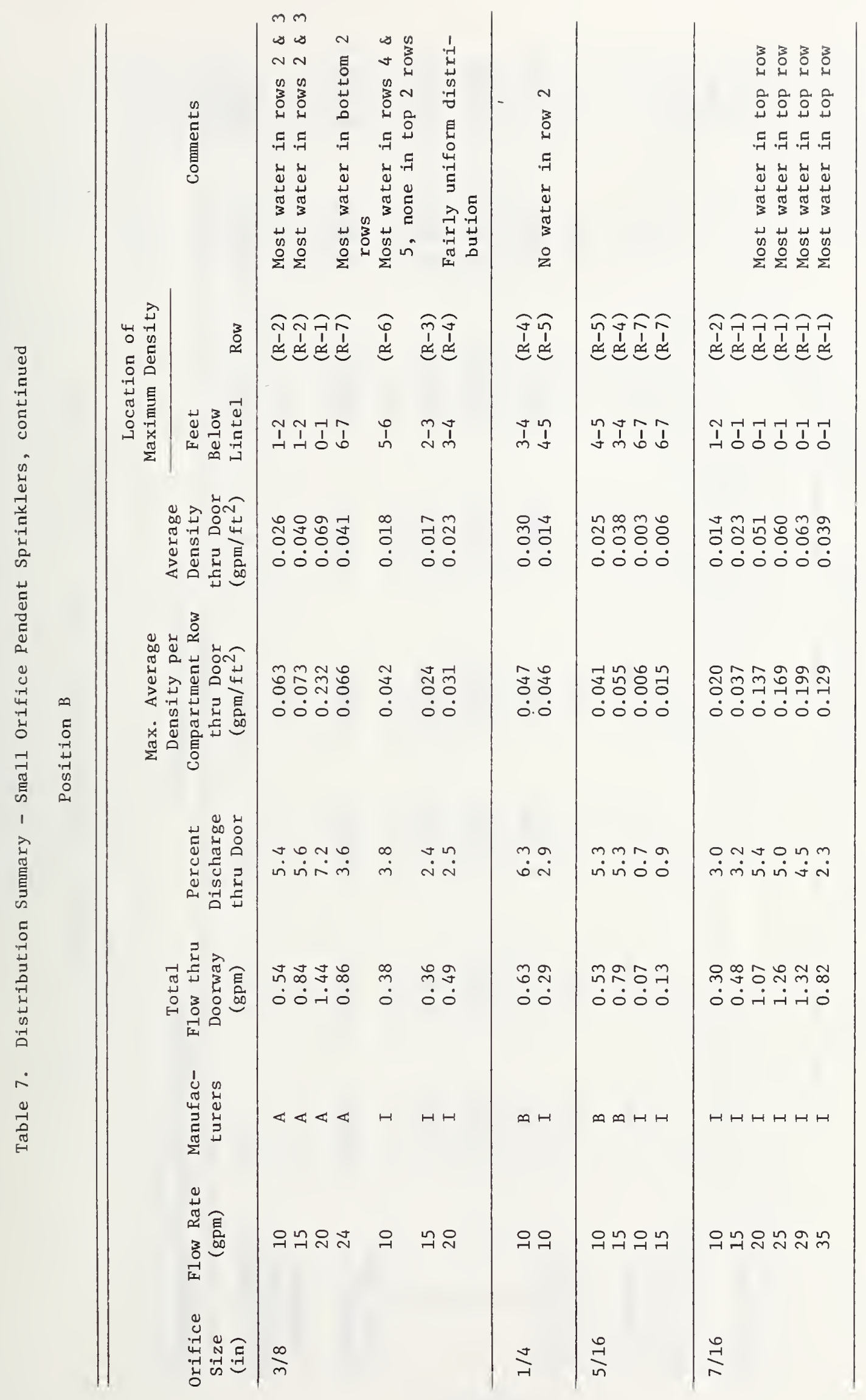












Table 10. Range of Average Density - I/2-Inch Pendent Sprinklers

Sprinkler

Flow Rate

(gPm)
Manufac-

turer
Max. Average

Density

$\left(\mathrm{gpm} / \mathrm{ft} \mathrm{t}^{2}\right)$
Percent

Difference

$\left(\mathrm{gpm} / \mathrm{ft} \mathrm{t}^{2}\right)$

\section{Position A}

10

15

20

25

30

35

10

15

20

25

30

35
(A) $\quad 0.022$

(A) 0.040

(B)

0.130

(G)

(B)

(F)

(B) os

(C)

(B)

(C)

(B) os

0.087

0.170

0.186

0.119

0.249

78.0

0.088

69.2

0.090

48.0

0.083

45.7

0.087

27.3

0.130

48.1

0.124

\section{Position B}

(D)

(F)

(D)

(F)

(B) os

$(B, I)$

(B) os

(A)

(I)

$(\mathrm{A}, \mathrm{F})$

(B) os

(A)
0.007

0.063

0.020

0.078

0.025

0.057

0.029

0.076

0.034

0.097

0.018

0.114
88.9

0.056

74.4

0.058

56.1

0.032

61.8

0.047

64.9

0.063

84.2

0.096 
Table 11. Range of Average Density - 3/8-Inch Pendent Sprinklers

\begin{tabular}{|c|c|c|c|c|}
\hline $\begin{array}{l}\text { Sprinkler } \\
\text { Flow Rate } \\
\text { (gpm) }\end{array}$ & $\begin{array}{c}\text { Manufac- } \\
\text { turers }\end{array}$ & $\begin{array}{c}\text { Max. Average } \\
\text { Density } \\
\left(g p m / f t^{2}\right)\end{array}$ & Percent & $\begin{array}{r}\text { Difference } \\
\left(\mathrm{gpm} / \mathrm{ft} \mathrm{t}^{2}\right)\end{array}$ \\
\hline \multicolumn{5}{|c|}{ Position A } \\
\hline 10 & $\begin{array}{l}\text { (I) } \\
\text { (A) }\end{array}$ & $\begin{array}{l}0.047 \\
0.050\end{array}$ & 6.0 & 0.003 \\
\hline 15 & $\begin{array}{l}\text { (A) } \\
\text { (I) }\end{array}$ & $\begin{array}{l}0.043 \\
0.061\end{array}$ & 29.5 & 0.018 \\
\hline 20 & $\begin{array}{l}\text { (I) } \\
\text { (A) }\end{array}$ & $\begin{array}{l}0.103 \\
0.105\end{array}$ & 1.9 & 0.002 \\
\hline \multicolumn{5}{|c|}{ Position B } \\
\hline 10 & $\begin{array}{l}\text { (I) } \\
\text { (A) }\end{array}$ & $\begin{array}{l}0.018 \\
0.026\end{array}$ & 30.8 & 0.008 \\
\hline 15 & $\begin{array}{l}\text { (I) } \\
\text { (A) }\end{array}$ & $\begin{array}{l}0.017 \\
0.040\end{array}$ & 57.5 & 0.023 \\
\hline 20 & $\begin{array}{l}\text { (I) } \\
\text { (A) }\end{array}$ & $\begin{array}{l}0.023 \\
0.069\end{array}$ & 66.7 & 0.046 \\
\hline
\end{tabular}


Table 12. Range of Average Density - 1/2-Inch Upright Sidewall Sprinklers

\begin{tabular}{|c|c|c|c|c|}
\hline $\begin{array}{l}\text { Sprinkler } \\
\text { Flow Rate } \\
\text { (gpm) }\end{array}$ & $\begin{array}{c}\text { Manufac- } \\
\text { turers }\end{array}$ & $\begin{array}{c}\text { Max. Average } \\
\text { Density } \\
\left(\mathrm{gpm} / \mathrm{ft}^{2}\right)\end{array}$ & Percent & $\begin{array}{r}\text { Difference } \\
\left(\mathrm{gpm} / \mathrm{ft}^{2}\right)\end{array}$ \\
\hline \multicolumn{5}{|c|}{ Position D } \\
\hline 10 & $\begin{array}{l}\text { (A) } \\
\text { (B) }\end{array}$ & $\begin{array}{l}0.131 \\
0.026\end{array}$ & 80.05 & 0.105 \\
\hline 15 & $\begin{array}{l}\text { (A) } \\
\text { (B) }\end{array}$ & $\begin{array}{l}0.169 \\
0.021\end{array}$ & 87.6 & 0.148 \\
\hline 20 & $\begin{array}{l}\text { (A) } \\
\text { (B) }\end{array}$ & $\begin{array}{l}0.203 \\
0.029\end{array}$ & 85.7 & 0.174 \\
\hline 25 & $\begin{array}{l}\text { (A) } \\
\text { (B) }\end{array}$ & $\begin{array}{l}0.203 \\
0.045\end{array}$ & 77.8 & 0.158 \\
\hline 30 & $\begin{array}{l}\text { (A) } \\
\text { (G) }\end{array}$ & $\begin{array}{l}0.265 \\
0.045\end{array}$ & 83.0 & 0.220 \\
\hline 35 & $\begin{array}{l}\text { (A) } \\
\text { (B) }\end{array}$ & $\begin{array}{l}0.317 \\
0.059\end{array}$ & 81.4 & 0.258 \\
\hline \multicolumn{5}{|c|}{ Position E } \\
\hline 10 & $\begin{array}{l}\text { (A) } \\
(\mathrm{E})\end{array}$ & $\begin{array}{l}0.055 \\
0.004\end{array}$ & 92.7 & 0.051 \\
\hline 15 & $\begin{array}{l}\text { (A) } \\
\text { (B) }\end{array}$ & $\begin{array}{l}0.075 \\
0.018\end{array}$ & 76.0 & 0.057 \\
\hline 20 & $\begin{array}{l}\text { (A) } \\
\text { (B) }\end{array}$ & $\begin{array}{l}0.088 \\
0.020\end{array}$ & 77.3 & 0.068 \\
\hline 25 & $\begin{array}{l}\text { (A) } \\
\text { (B) }\end{array}$ & $\begin{array}{l}0.119 \\
0.028\end{array}$ & 76.5 & 0.091 \\
\hline 30 & $\begin{array}{l}\text { (A) } \\
\text { (B) }\end{array}$ & $\begin{array}{l}0.139 \\
0.041\end{array}$ & 70.5 & 0.099 \\
\hline 35 & $\begin{array}{l}\text { (D) } \\
\text { (C) }\end{array}$ & $\begin{array}{l}0.119 \\
0.051\end{array}$ & 57.1 & 0.68 \\
\hline
\end{tabular}


Table 13. Range of Maximum Average Density per Row of Compartments - 1/2-Inch Pendent Sprinklers

\begin{tabular}{|c|c|c|c|c|}
\hline $\begin{array}{c}\text { Sprinkler } \\
\text { Flow Rate } \\
\text { (gpm) }\end{array}$ & $\begin{array}{l}\text { Manufac- } \\
\text { turers }\end{array}$ & $\begin{array}{c}\text { Max. Average } \\
\text { Density } \\
\left(\mathrm{gpm} / \mathrm{ft}^{2}\right)\end{array}$ & Percent & $\begin{array}{r}\text { Difference } \\
\left(\mathrm{gpm} / \mathrm{ft}^{2}\right)\end{array}$ \\
\hline \multicolumn{5}{|c|}{ Position A } \\
\hline 10 & $\begin{array}{l}\text { (A) } \\
\text { (F) }\end{array}$ & $\begin{array}{l}0.061 \\
0.400\end{array}$ & 84.8 & 0.339 \\
\hline 15 & $\begin{array}{l}\text { (A) } \\
\text { (F) }\end{array}$ & $\begin{array}{l}0.088 \\
0.378\end{array}$ & 76.7 & 0.290 \\
\hline 20 & $\begin{array}{l}\text { (D) } \\
\text { (F) }\end{array}$ & $\begin{array}{l}0.153 \\
0.667\end{array}$ & 77.1 & 0.514 \\
\hline 25 & $\begin{array}{l}\text { (D) } \\
\text { (F) }\end{array}$ & $\begin{array}{l}0.214 \\
0.703\end{array}$ & 69.6 & 0.489 \\
\hline 30 & $\begin{array}{l}\text { (D) } \\
\text { (F) }\end{array}$ & $\begin{array}{l}0.246 \\
0.642\end{array}$ & 61.7 & 0.396 \\
\hline 35 & $\begin{array}{l}\text { (D) } \\
\text { (F) }\end{array}$ & $\begin{array}{l}0.311 \\
1.073\end{array}$ & 71.0 & 0.762 \\
\hline \multicolumn{5}{|c|}{ Position B } \\
\hline 10 & $\begin{array}{l}\text { (D) } \\
\text { (F) }\end{array}$ & $\begin{array}{l}0.018 \\
0.202\end{array}$ & 91.1 & 0.184 \\
\hline 15 & $\begin{array}{l}\text { (D) } \\
\text { (F) }\end{array}$ & $\begin{array}{l}0.030 \\
0.344\end{array}$ & 91.3 & 0.314 \\
\hline 20 & $\begin{array}{l}\text { (B)os } \\
\text { (F) }\end{array}$ & $\begin{array}{l}0.039 \\
0.182\end{array}$ & 78.6 & 0.143 \\
\hline 25 & $\begin{array}{l}\text { (B) os } \\
\text { (F) }\end{array}$ & $\begin{array}{l}0.050 \\
0.275\end{array}$ & 81.8 & 0.225 \\
\hline 30 & $\begin{array}{l}\text { (B)os } \\
\text { (F) }\end{array}$ & $\begin{array}{l}0.065 \\
0.465\end{array}$ & 86.0 & 0.400 \\
\hline 35 & $\begin{array}{l}\text { (B)os } \\
\text { (F) }\end{array}$ & $\begin{array}{l}0.028 \\
0.548\end{array}$ & 94.9 & 0.520 \\
\hline
\end{tabular}


Table 14. Range of Maximum Average Density per Row of Compartments 3/8-Inch Pendent Sprinklers

\begin{tabular}{|c|c|c|c|c|}
\hline $\begin{array}{l}\text { Sprinkler } \\
\text { Flow Rate } \\
\text { (gpm) }\end{array}$ & $\begin{array}{c}\text { Manufac- } \\
\text { turers }\end{array}$ & $\begin{array}{c}\text { Max. Average } \\
\text { Density } \\
\left(\mathrm{gpm} / \mathrm{ft} \mathrm{t}^{2}\right)\end{array}$ & Percent & $\begin{array}{r}\text { Difference } \\
\left(\mathrm{gpm} / \mathrm{ft}^{2}\right)\end{array}$ \\
\hline \multicolumn{5}{|c|}{ Position A } \\
\hline 10 & $\begin{array}{l}(\mathrm{I}) \\
(\mathrm{A})\end{array}$ & $\begin{array}{l}0.065 \\
0.149\end{array}$ & 56.4 & 0.084 \\
\hline 15 & $\begin{array}{l}\text { (I) } \\
\text { (A) }\end{array}$ & $\begin{array}{l}0.089 \\
0.177\end{array}$ & 49.7 & 0.088 \\
\hline 20 & $\begin{array}{l}\text { (I) } \\
\text { (A) }\end{array}$ & $\begin{array}{l}0.149 \\
0.448\end{array}$ & 66.4 & 0.299 \\
\hline \multicolumn{5}{|c|}{ Position B } \\
\hline 10 & $\begin{array}{l}\text { (I) } \\
(\mathrm{A})\end{array}$ & $\begin{array}{l}0.042 \\
0.063\end{array}$ & 30.2 & 0.021 \\
\hline 15 & $\begin{array}{l}\text { (I) } \\
\text { (A) }\end{array}$ & $\begin{array}{l}0.024 \\
0.073\end{array}$ & 67.1 & 0.049 \\
\hline 20 & $\begin{array}{l}\text { (I) } \\
\text { (A) }\end{array}$ & $\begin{array}{l}0.031 \\
0.232\end{array}$ & 86.6 & 0.201 \\
\hline
\end{tabular}


Table 15. Range of Maximum Average Density per Row of Compartments 1/2-Inch Sidewall Sprinklers

\begin{tabular}{|c|c|c|c|c|}
\hline $\begin{array}{l}\text { Sprinkler } \\
\text { Flow Rate } \\
\text { (gpm) }\end{array}$ & $\begin{array}{c}\text { Manufac- } \\
\text { turers }\end{array}$ & $\begin{array}{c}\text { Max. Average } \\
\text { Density } \\
\left(\mathrm{gpm} / \mathrm{ft}^{2}\right)\end{array}$ & Percent & $\begin{array}{l}\text { Difference } \\
\left(\mathrm{gpm} / \mathrm{ft}^{2}\right)\end{array}$ \\
\hline \multicolumn{5}{|c|}{ Position D } \\
\hline 10 & $\begin{array}{l}\text { (A) } \\
\text { (C) }\end{array}$ & $\begin{array}{l}0.447 \\
0.044\end{array}$ & 90.2 & 0.403 \\
\hline 15 & $\begin{array}{l}\text { (A) } \\
\text { (B) }\end{array}$ & $\begin{array}{l}0.580 \\
0.039\end{array}$ & 93.3 & 0.541 \\
\hline 20 & $\begin{array}{l}\text { (A) } \\
\text { (B) }\end{array}$ & $\begin{array}{l}0.795 \\
0.066\end{array}$ & 92.5 & 0.729 \\
\hline 25 & $\begin{array}{l}\text { (A) } \\
\text { (B) }\end{array}$ & $\begin{array}{l}0.774 \\
0.084\end{array}$ & 89.2 & 0.690 \\
\hline 30 & $\begin{array}{l}\text { (A) } \\
\text { (B) }\end{array}$ & $\begin{array}{l}1.060 \\
0.104\end{array}$ & 90.2 & 0.956 \\
\hline 35 & $\begin{array}{l}\text { (A) } \\
\text { (C) }\end{array}$ & $\begin{array}{l}1.080 \\
0.116\end{array}$ & 89.3 & 0.964 \\
\hline \multicolumn{5}{|c|}{ Position E } \\
\hline 10 & $\begin{array}{l}\text { (G) } \\
\text { (C) }\end{array}$ & $\begin{array}{l}0.182 \\
0.040\end{array}$ & 78.0 & 0.142 \\
\hline 15 & $\begin{array}{l}\text { (A) } \\
\text { (B) }\end{array}$ & $\begin{array}{l}0.206 \\
0.036\end{array}$ & 85.5 & 0.170 \\
\hline 20 & $\begin{array}{l}\text { (A) } \\
\text { (B) }\end{array}$ & $\begin{array}{l}0.200 \\
0.035\end{array}$ & 85.5 & 0.165 \\
\hline 25 & $\begin{array}{l}\text { (A) } \\
\text { (B) }\end{array}$ & $\begin{array}{r}0.257 \\
.0 .067\end{array}$ & 73.9 & 0.190 \\
\hline 30 & $\begin{array}{l}\text { (A) } \\
\text { (C) }\end{array}$ & $\begin{array}{l}0.290 \\
0.073\end{array}$ & 74.3 & 0.217 \\
\hline 35 & $\begin{array}{l}\text { (D) } \\
\text { (C) }\end{array}$ & $\begin{array}{l}0.371 \\
0.093\end{array}$ & 74.9 & 0.278 \\
\hline
\end{tabular}




\begin{tabular}{|c|c|c|c|}
\hline $\begin{array}{l}\text { U.S. DEPT. OF COMM. } \\
\text { BIBLIOGRAPHIC DATA } \\
\text { SHEET }\end{array}$ & $\begin{array}{l}\text { 1. PUBLICATION OR REPORT NO. } \\
\text { NBSIR 75-920 }\end{array}$ & $\begin{array}{l}\text { 2. Gov't Accession } \\
\text { No. }\end{array}$ & 3. Recipient's Accession No. \\
\hline \multirow{2}{*}{\multicolumn{3}{|c|}{$\begin{array}{l}\text { 4. TITLE AND SUBTITLE } \\
\text { DISTRIBUTION OF WATER THROUGH A VERTICAL PLANE } \\
\text { FROM AUTOMATIC SPRINKLER HEADS }\end{array}$}} & \multirow{2}{*}{$\begin{array}{l}\text { 5. Publication Date } \\
\text { December } 1975 \\
\text { 6. Performing Organization Code }\end{array}$} \\
\hline & & & \\
\hline \multicolumn{3}{|c|}{$\begin{array}{l}\text { 7. AUTHOR(S) } \\
\text { Richard L. P. Custer and Klaus Wahle }\end{array}$} & 8. Performing Organ. Report No. \\
\hline \multirow{2}{*}{\multicolumn{3}{|c|}{$\begin{array}{l}\text { 9. PERFORMING ORGANIZATION NAME AND ADDRESS } \\
\text { NATIONAL BUREAU OF STANDARDS } \\
\text { DEPARTMENT OF COMMERCE } \\
\text { WASHINGTON, D.C. } 20234\end{array}$}} & $\begin{array}{l}\text { 10. Project/Task/Work Unit No. } \\
4928416\end{array}$ \\
\hline & & & $\begin{array}{l}\text { 11. Contract/Grant No. } \\
\text { IAA-H-37-32 }\end{array}$ \\
\hline \multirow{2}{*}{\multicolumn{3}{|c|}{$\begin{array}{l}\text { 12. Sponsoring Organization Name and Complete Address (Street, City, State, ZIP) } \\
\text { Division of Energy, Building Technology and Standards } \\
\text { Office of Policy Development and Research } \\
\text { Department of Housing and Urban Development } \\
\text { Washington, D.C. } 20410\end{array}$}} & $\begin{array}{l}\text { 13. Type of Report \& Period } \\
\text { Covered } \\
\text { Interim Report }\end{array}$ \\
\hline & & & 14. Sponsoring Agency Code \\
\hline
\end{tabular}

15. SUPPLEMENTARY NOTES

16. ABSTRACT (A 200-word or less factual summary of most significant in formation. If document includes a significant bibliography or literature survey, mention it here.)

An investigation was conducted to evaluate the distribution of water through a vertical plane from automatic sprinkler heads as a function of water discharge rate and sprinkler spacing. Tests were conducted to simulate discharging an automatic sprinkler head in a corridor to determine the effectiveness of the sprinkler head in covering a doorway with water spray when positioned at various locations. Major differences in distribution characteristics between sprinkler heads produced by different manufacturers were observed. It was determined that only sprinklers installed on the centerline of the doorway and discharging water at a flow rate of 20 gallons-per-minute or more would cover the top of the doorway.

17. KEY WORDS (six to twelve entries; alphabetical order; capitalize only the first letter of the first key word unless a proper name; separated by semicolons) Automatic sprinkler; corridor sprinkler systems; discharge patterns; spray distribution; water distribution; water spray.

\begin{tabular}{|c|c|c|}
\hline 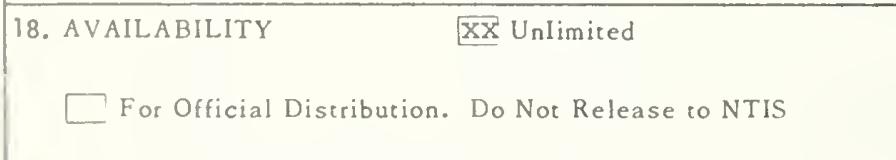 & $\begin{array}{l}\text { 19. SECURITY CLASS } \\
\text { (THIS REPURT) } \\
\text { UNCL ASSIFIED }\end{array}$ & $\begin{array}{l}\text { 21. NO. OF PAGES } \\
41\end{array}$ \\
\hline $\begin{array}{l}\square \text { Order From Sup. of Doc., U.S. Government Printing Office } \\
\text { Washington, D.C. } 20402, \text { SD Cat. No.C13 }\end{array}$ & $\begin{array}{l}\text { 20. SECURITY CLASS } \\
\text { (THIS PAGE) }\end{array}$ & 22. Price \\
\hline $\begin{array}{l}\square \text { Order From National Technical Information Service (NTIS) } \\
\text { Springfield, Virginia } 22151\end{array}$ & UNCLASSIFIED & \\
\hline
\end{tabular}





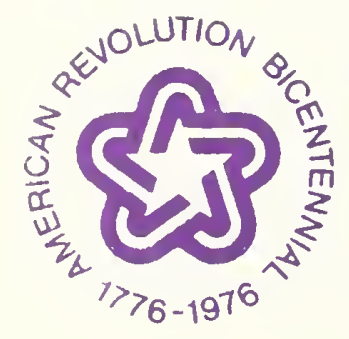

